\title{
Investigation of Potential Analytical Methods for Redox Control of the Vitrification Process
}

\author{
D. S. Goldman
}

November 1985

s

Prepared for the U.S. Department of Energy under Contract DE-AC06-76RLO 1830

Pacific Northwest Laboratory Operated for the U.S. Department of Energy by Battelle Memorial Institute 


\title{
DISCLAIMER
}

This report was prepared as an account of work sponsored by an agency of the United States Government. Neither the United States Government nor any agency thereof, nor any of their employees, makes any warranty, express or implied, or assumes any legal liability or responsibility for the accuracy, completeness, or usefulness of any information, apparatus, product, or process disclosed, or represents that its use would not infringe privately owned rights. Reference herein to any specific commercial product, process, or service by trade name, trademark. manufacturer, or otherwise, does not necessarily constitute or imply its endorsement, recommendation, or favoring by the United States Government or any agency thereof. The views and opinions of authors expressed herein do not necessarily state or reflect those of the United States Government or any agency thereof.

\author{
PACIFIC NORTHWEST LABORATORY \\ operated by \\ BATTELLE \\ for the \\ UNITED STATES DEPARTMENT OF ENERGY \\ under Contract DE-AC06-76RLO 1830
}

\begin{tabular}{|c|c|}
\hline \multirow{2}{*}{\multicolumn{2}{|c|}{ Printed in the United States of America }} \\
\hline & \\
\hline \multicolumn{2}{|c|}{$\begin{array}{l}\text { Available from } \\
\text { National Technical Information Service }\end{array}$} \\
\hline \multicolumn{2}{|c|}{ United States Department of Commerce } \\
\hline \multicolumn{2}{|c|}{5285 Port Royal Road } \\
\hline \multicolumn{2}{|c|}{ Springfield, Virginia 22161} \\
\hline \multirow{2}{*}{\multicolumn{2}{|c|}{$\begin{array}{l}\text { NTIS Price Codes } \\
\text { Microfiche A01 }\end{array}$}} \\
\hline & \\
\hline \multicolumn{2}{|c|}{ Printed Copy } \\
\hline & Price \\
\hline Pages & Codes \\
\hline $001-025$ & $\mathrm{~A} 02$ \\
\hline $026-050$ & $\mathrm{~A} 03$ \\
\hline $051-075$ & $A O S$ \\
\hline $076-100$ & A 05 \\
\hline $101-125$ & $A 06$ \\
\hline 126.150 & $A 0 F$ \\
\hline 151.175 & 100 \\
\hline $176-200$ & $\wedge 09$ \\
\hline $201-225$ & A010 \\
\hline $226-250$ & A011 \\
\hline 251.275 & $\mathrm{~A} 012$ \\
\hline $276-300$ & $A 013$ \\
\hline
\end{tabular}


INVESTIGATION OF POTENTIAL ANALYTICAL

METHODS FOR REOOX CONTROL OF THE

VITRIFICATION PROCESS

0. S. Goldman

November 1995

Prepared for the U.S. Departinent of Energy under Contract DE-ALOC-76RLO 1830

Pacific Northwest Laboratory

Richland, washington 99352 


\section{ACKNOWLEDGMENTS}

The author would like to thank 0r. J. Spizkerman of Ranger Scientific, "nc., for assistance with the Hossbauer instrumentation and helpful discusstons zuring the course of this work; D. E. Bewley, a NORCus (Northwest College and University ssociation for science) student, for assistance with most of the Mossbauer analyses of nonradjoactive samples; C. A. Knox and R. E. Thormill For construction of the shielded Mossbauer container and for preparation of the fadioactive glass; G. F. Rodkey for preparation of the samples for color analyșis; K. A. Stahl for the reflectance spectral neasurements: M. C. Burt (Hantord Engineering Development Laboratory) for ferrous/ferric analyses of the uranium and thorium waste glasses; and $A$. W. Lautensleger for identification and testing of the ion chronatograph for ferrous/ferric analyses of the glass. 
,

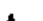

•

. 


\section{ABSTRACT}

An investigation was conducted to evaluate several analytical techniques to measure ferrous/ferric ratios in simulated and radioactive nuclear waste glasses for eventual redox control of the vitrification process. Redox control will minimize the melt foaming that occurs under highly oxidizing conditions and the metal precipltation that occurs under highly reducing condtions. The analytal method selected must have a rapid response for producton problems with minimal complexity and andyst involvenent. The wet-chemistry, Mossbaver spectroscopy, glass color analysis, and ion chromatography techniques were explored, with particular emphasis being placed on the Mossbauer technique. In general, all of these methods can be used for nonradioactive samples. The : A snielded container was destgned and built to analyze fully radioactute jlasses with the Mossbauer spectrometer in a hot cell environthent. However, analyses conducted with radodctive waste glasses containing $90 \mathrm{Sr}$ and ${ }^{137} \mathrm{Cs}$ were unsuccessful, presumably due to background radiation problems cased by the sanples. The color of glass powder can be used to analyze the ferrous/ ferric ratio for low chromun glasses, but this method may not be as prectse as the others. Ion chronatography was only tested on non adioactive glasses, but this technlque appears to have the required prectsion due to its analysis of soth fet. and $\mathrm{Fe}^{+3}$ and its antclpated adaptabllity for radioactivity sanples. This development would be simllar to procedures already in use for shielded inductively coupled plasma emisston (ICP) spectrometry. Development of the ion whromatography method is therefore recomended; conventional wet-chentstry is recomnended as a backup procedure. 


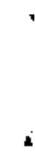




\section{EXECUTIVE SUMMARY}

An investigation was conducted to evaluata several analytical techniques that measure ferrous/ferric ratios in simulated and radioactive nuclear waste glasses for eventual redox control of the vitrification process. Redox control witl minimize the nelt foaming that occurs under highly oxidizing conditions and the netal precipitation that occurs under highly reducing conditors. The analytical method selected must have a rapid response for production problens with minimal analytical complexity and analyst involvement. The wetchemistry, mossbauer spectroscopy, glass color analysis, and ion chromatography techniques were explored, with particular emphasis being placed on the Mossbauer method.

A linear correlation was established for ferrous/ferric ratios determined 2y wetchemistry and wossauer spectroscopy. The wet-chenistry procedure is a complexinetric, colorimetric nethod that is specific for iron and can be con ducted without the need for an inert atmosphere during sample digestion. Area fatios from nonlinear regression analysis of the Mossbauer spectra are generally used directly to determine the ferrous/ferric ratio. The results of this study show that this common assumption will overestimate the ferrous/ferric ratio by $50 \%$. This correlation contains a varlety of simple and complex 3lasses, some of which contain only iron as the miltivalent spectes. This suggests that the wet-chemistry procedure is not biasd by the presence of the various multivalent jons that are present during sample digestion and suggests that the bias lies with the Mossbauer method. Another common assumption in fitting Mossbauer spectra is the constancy of the peak line shape, which is usually fixed at $100 \%$ Lorentzian. The results of this study show that this assumption is generally not vald for silicate and borosilicate glasses.

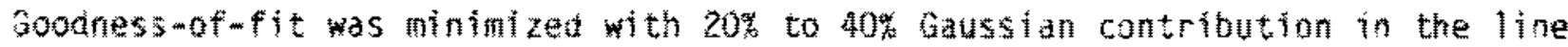
shape, with an increasing laussian component at lower ferrous/ferric ratos* Variations in line shape did not affect the resulting ferrous/ferric ratios for the more reduced sarples (ferrous/ferric ratios near 1.0), whereas a considerable dependence was observed for more oxidized samples. The linear calibration with wet-chemistry was only achieved using the area ratios after optimizing the ine shape to minimize the goodness-of-fịt paraneter for each hosshaver spectrum. A procedure was also proposed to rapidly measure the ferroustereric 
ratios using raw intensity data at only three velocity locatons without the need of spectral fitting. The Mösbauer method readily analyzed waste glasses containing urantum and thoriun. However testing of fully radioactive samples containing $90 \mathrm{sr}$ and $137 \mathrm{Cs}$ in a spectally designed, shielded container was not successful, apparently due to a high radjation background from these radionuclides.

The color of glass powder changes from light to dark brown as the ferrous/ ferric ratio increases in simulated waste glass. Reflectance spectra of packed powder was therefore used in an attempt to quantify these differences. The reflectance data were then used to calculate the chromaticity or color coordim nate values using standard procedures. These values were used to calculate a parameter referred to as spectral purfty, which was found to correlate with the ferrousterric ratio neasured in the glass by wetchemistry. Although reprom ducibllity could be imoroved with better sample preparation procedures, this method is complicated by potential variations in the chromial content of the sample. The strong trend defined at 0.2 wth $\mathrm{Cr}_{2} \mathrm{O}_{3}$ is almost completery obscured at values near 0.75 wto $\mathrm{Cr}_{2} \mathrm{O}_{3}$. Therefore, different calibrations are required for differing amounts of chromium in the glass. Nevertheless, this method may be useful as a screentag tool for nominally low chromium glasses to deternine if further ferrous/ferric analyses are required with one of the other inethods.

A study was conducted to determine the feasibility of using ton chromatoumraphy for the analysis of the ferrous/ferric rato in wasteglasses. This technique is attractive due to its reported sensitivity for difect andysis of both ferrous and ferric tons in solution and its sinilarity to inductively coupled plasma emission spectrometry, which has already been used for fully radioactive samples. The results show that the ferrous content can be corm rectly determined wh this method. Additional testing tine was not avallable to determine if a simple dilution of the digestion solution could be used to andyze the ferric content, since the method has greater sensitivity for the ferrito ion.

The results of this study suggest that additional work should focus on development of the ion chromatography method. This method is perceived to be precise, rapid, and readily adaptable for use with radioactive sanples. The conventional wet-chemistry technique is recommended as a backup procedure. 


\section{CONTENTS}

ACKNOWLEDGUENTS $\ldots \ldots \ldots \ldots \ldots \ldots \ldots \ldots \ldots \ldots \ldots \ldots \ldots \ldots \ldots \ldots \ldots \ldots \ldots \ldots \ldots \ldots \ldots$ H $\ldots \ldots \ldots$

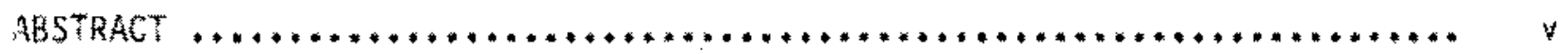

EXECUTIVE SUMMARY $\ldots \ldots \ldots+\ldots \ldots \ldots \ldots \ldots \ldots+\ldots * \ldots \ldots \ldots \ldots \ldots \ldots \ldots \ldots \ldots \ldots+\ldots \ldots \ldots \ldots$ WII

INTROLUCTION $\ldots \ldots \ldots \ldots \ldots \ldots \ldots \ldots \ldots \ldots \ldots \ldots \ldots \ldots \ldots \ldots \ldots \ldots \ldots \ldots \ldots \ldots \ldots \ldots \ldots \ldots \ldots \ldots$

MOSSBALER SPECTROSCOPY AND WET -CHEMISTRY $\ldots \ldots \ldots \ldots \ldots \ldots \ldots \ldots \ldots \ldots \ldots \ldots \ldots \ldots$

EXPERIMENTAL METHODS $\ldots \ldots \ldots \ldots \ldots \ldots \ldots \ldots \ldots \ldots \ldots \ldots \ldots \ldots \ldots \ldots \ldots \ldots \ldots \ldots \ldots \ldots 4$

Wet -Chentstry $\ldots \ldots \ldots \ldots \ldots \ldots \ldots \ldots \ldots \ldots \ldots \ldots \ldots \ldots \ldots * \ldots \ldots \ldots \ldots \ldots \ldots, 4$

Mossbauer Spectroscopy $\ldots \ldots \ldots \ldots \ldots \ldots \ldots \ldots \ldots \ldots \ldots \ldots \ldots \ldots \ldots \ldots$

RESUITS $\ldots \ldots \ldots \ldots \ldots \ldots \ldots \ldots \ldots \ldots \ldots \ldots \ldots \ldots \ldots \ldots \ldots \ldots \ldots \ldots \ldots \ldots \ldots \ldots \ldots, 8$

Mossbauer Spectra $\ldots \ldots \ldots+\ldots \ldots \ldots \ldots \ldots \ldots \ldots \ldots \ldots * \ldots \ldots \ldots \ldots \ldots \ldots \ldots \ldots \ldots \ldots$.

Line shape $\ldots \ldots \ldots \ldots \ldots \ldots \ldots \ldots \ldots \ldots \ldots \ldots \ldots \ldots \ldots \ldots \ldots \ldots \ldots \ldots \ldots \ldots \ldots \ldots \ldots$ n

Mossbauer het-Chemistry Correlation $\ldots \ldots \ldots \ldots \ldots \ldots \ldots \ldots \ldots \ldots \ldots . . \ldots \ldots$

Additional Ferrous Peaks $\ldots \ldots \ldots \ldots \ldots \ldots \ldots \ldots \ldots \ldots \ldots \ldots \ldots \ldots \ldots 13$

Correlation with Measured Intensity bata $\ldots \ldots \ldots \ldots \ldots \ldots \ldots \ldots . . \ldots 14$

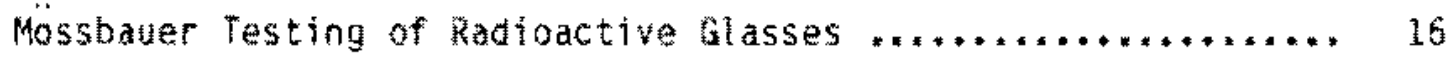

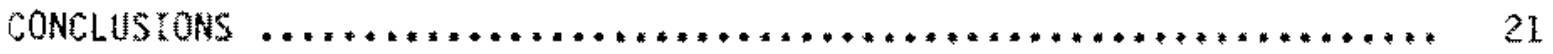

COLOR ANALYSIS Of GLASS POWOER $\ldots \ldots \ldots \ldots \ldots \ldots \ldots \ldots \ldots \ldots \ldots \ldots \ldots \ldots \ldots \ldots \ldots \ldots$

COLORIMETRY $\ldots \ldots \ldots+\ldots * \ldots \ldots \ldots \ldots \ldots \ldots \ldots \ldots \ldots \ldots \ldots \ldots \ldots \ldots \ldots \ldots \ldots \ldots \ldots \ldots \ldots \quad 23$

EXPERIMENTAL METHONS $\ldots \ldots \ldots * \ldots \ldots \ldots \ldots \ldots \ldots \ldots \ldots \ldots \ldots \ldots \ldots \ldots \ldots \ldots \ldots+24$

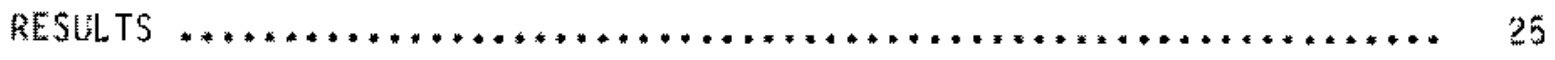

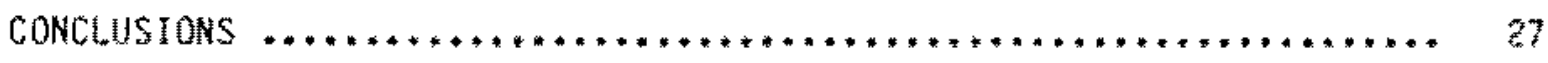

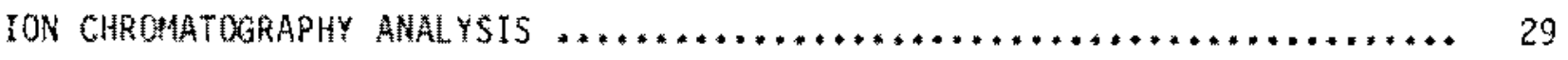

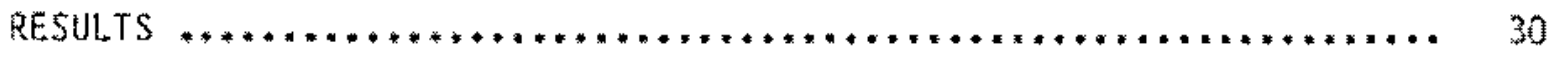

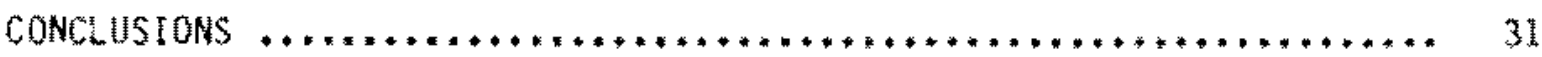

REFERENCES $\ldots \ldots \ldots \ldots \ldots \ldots \ldots \ldots \ldots \ldots \ldots \ldots \ldots \ldots \ldots \ldots \ldots \ldots \ldots \ldots \ldots \ldots \ldots \ldots \ldots \ldots \ldots \ldots \ldots$ 


\section{FIGURES}

1 Mossbatwer Spectra of Simulated Hanford, West Valley, and Savannah River Glasses Prepared at PNL.

2 Effect of Varying the Peak Line Shape in the Mossbaver Spectrum of Sample 5, Showing a Statistical Optimun at 50 is Lorentzian

3 Effect of Varying the Peak Line Shape in the Mossbauer Spectrun of sample 3, Showing a Statlstical Optimum at About 70 Lorentzian $\ldots \ldots$.

4 Correlation of Ferrous/Total Iron Ratios Detemined by WetChemistry and Mossbauer Spectroscopy

5 Mossbauer Spectrum of Sample 5 Fitted with an Additional

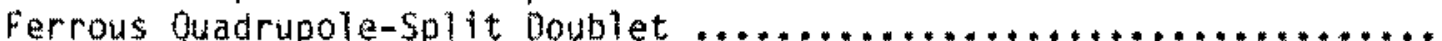

6 Correlation of Mossbauer Intensity Data with the Ferrous/Ferric Ratio Deternined from Wet-chenistry

7 Mossauer System for Radioactive Samples $\ldots \ldots \ldots \ldots \ldots \ldots \ldots \ldots * \ldots * \ldots \ldots$ lo

8 Mossbauer Spectrum of West Valley Glass Containing Uranium and Thorium

9 Color Analysis of Glass Powder of an Oxidized Simulated West valley glass *...................................... 25

10 Effect of Redox on the color of simulated West Walley Giass $\ldots \ldots \ldots \ldots$. 25

11 Separation of Transition Metals Using Hplcycss Separator Column ..... 29

\section{TABLES}

1 Ferrous/Ferric Wet Chenistry Analysis of Sample $13 \ldots \ldots \ldots \ldots \ldots \ldots \ldots \ldots$

2 Summary of Hossbuer and Wetmenistry Data $\ldots \ldots \ldots \ldots \ldots \ldots \ldots \ldots \ldots \ldots \ldots \ldots$ I

3 Results of Ion Chronatography (IC) Analysis of the Ferrous/Ferric Ratio 
INTRODUCTION

The ferrous/ferric ratio in nuclear waste glass is a viable redox indiwator that can be used for redox process control. Conditions that are too oxilizing may lead to melt foaming and process downtime. Conditions that are too reducing may lead to the formation of conductive phases that can settle and potentially cause an electrical short between the submersed electrodes. These constraints point to the need for process control at a moderate state of reduccion and, hence, an efficient means to analyze the ferrous/ferric ratio. The technique must be reasonably rapid to support process decisions and easy to Derform to minimize manpower costs. In addition, the method must be adaptable for the radiadive glasses that will be used in a full-scale operation.

The purpose of this report is to summarize the work conducted by pacific Northwest Laboratory (PNL) (a) in FY 1985 to assess several analytical methods for the measurement of the ferrous/ferric ratio. These nethods include Mossbauer spectroscopy, wet-chemistry, color analysis, and ion chromatography. It is possible that several methods could be used in conjunction, depending on the circumstances. Thus, the intent of this report is to provide a basis for selecting a method that can be used when sufficient experience with the process is gained so that the analytical requirements are precisely known. The goal is to minimize the analytical complexity and the andysis time required to conduct these measurements to better support the vitrification process.

(a) Operated for the U.S. Department of Energy (DOE) by Battelle Menlorial Institute under contract DE-ACO6-76RLO 1830. 


\section{MOSSBAUER SPECTROSCOPY AND WET-CHEMISTRY}

High-level nuclear waste in the United States will be incorporated into a chemically durable glass matrix, sealed in a steel container, and disposed of in a designated federal repository. The glass-forming chemicals and waste material will be combined into a liquid slurry and mel ted into a borosilicate glass in an electric melter. The entire vitrification process will be operated remotely. Therefore, few melting problems can be tolerated.

The control of the oxidation state of the molten glass in the meiter is of paramount importance in optimizing the melting process. Highly oxidizing conditions tend to induce gas solubility reactions that lead to the formation of a stable layer of glass foam on the melt surface (boldman, Brite, and Richey 1985). This foam layer interferes with heat transfer and impairs processing rates. Highly reducing conditions may cause the formation of conductive phases in the meit (Schreiber et at. 1983). These phases can settle to the melter floor, form a conductive layer between the submersed electrodes, and cause an electrical short. Therefore, a range of oxidation states must be defined to minimize the occurrence of these melting problems, and a means to accurately neasure the oxidation state of the glass must be developed.

The possibility of using ${ }^{57} \mathrm{Fe}$ Mossbauer spectroscopy to measure the ferrous/ferric ratio in these glasses to monitor the glass oxidation state has been investigated. The common usage of a completely Lorentzian line shape in the fitting procedure and the assumption that the area ratios equal the concentration ratios (for example, Mysen and Virgo 1978) were tested, The alkaltiron-borosilicate glasses presently considered for nuclear waste disposal contain between 5 to and 10 wt Fe, making them readily anenable for andysis by the Mosstater technique. In addition, Goldman (1983), Schreiber et at. (1984), and Goldman and Brite (1985) demonstrated that the ferrous/ferric ratio can be used as a quantitative indicator of the glass oxidation state in borosilicate glass, Goldman and Brite (1985) demonstrated this possibility even for a 
compostionally complex simulated nuclear waste glass al containing several other multident species that interact with the iron redox couple.

The first objective of this study was to compare ferrous/ferric ratios detemined by wet-chemistry and Mössbauer spectroscopy for the same samples. Potential errors with the wet-chemistry method were evaluated, including the effect of the surrounding atmosphere during sample digestion and the effect that the presence of other multivalent spectes may have on the results* potential errors associated with the Mossbaver method were also examined, including the assunption of a particular line shape in the spectral fitting procedure and the assumption that the fitted area ratio represents the concentration ratio. The second objective was to evaluate if ferrous/ferric ratios can be determined more rapidly using measuredmintensity Mossbauer data, If successful, this procedure wold also eliminate the need for spectral fitting, which is consistent with a longer-range goal of this work to provide a rapid, simple analytical procadure to better support the varification process in the plant envilonment.

EXPERIMENTAL METHÖOS

Wet-Chemistry

A compleximetric, colorinetric procedure developed for the gass industry by Jones, wansheski, and Goldman (1981) was used to determine the ferrous ferric ratios. This method has several advantages. First, the use of phenan throlene makes it spectfic for iron unlike the earlier titrimetric methods for example, close and Tillman 1969 ) that remain prevalent in the glass industry today. Second, only one acid digestion is required. The ferrous iron initially released forms an orange-colored complex with 1,10-phenanthrolene for direct measurement of the ferrous iron concentration. The total iron concentration is then measured by reducing the remaining fartic iron in solution with

(a) Simulated nuclear waste glasses are currently betng developed for defense wastes at Savannah River, South Carolina, and Hanford, Washington, and for the commercial waste at west Valley. New York. Although the final composition of these glasses has yet to be decided, they can be described as containing 40 to 55 wt: 5102,7 to 15 wt $\mathrm{B}_{2} \mathrm{O}_{3}, 7$ to 12 wtw Fent, 10 to

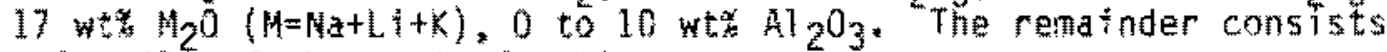
primarily of the waste fraction. 
hydroquinone. The ferric iron content of the glass is then deterwited by the difference in these measured quantitles. Third, the mathod can be conducted without the need for an inert atmosphere during sample digestion. A sample was digested in air and in ultrahigh purity argon. The results did not indicate that the surrounding atmosphere had any effect at a confidence level of $99 \%$ (Table 1). Fourth, the procedure is rapid and easy to perform with excellent reproduciblitty. The average error on a ferrousmo-total iron (FTI) ratio is generally less than a for a 20me glass sample. The minimum detection limit for ferrous fron using this nethod is approximately 0.005 wt/ Fe. faven that most glasses considered here have greater than 5 o Fe as total iron, the minimum ferrous/ferric ratio that can be measured is about 0.001 . Thus, suffictent analytical senstivity is avallable to analyze any sample that could produce a detectable ferrous peak in a Mossbauer spectrum. The remaining glass powter for each sample was used for the Mossbauer experinents.

\section{Mossbauer Spectroscopy}

Mossbatuer spectroscopy is a nucledr resonanct technique that involves the recolless amission and absorption of $14.4 \mathrm{mkel}$ ganma radiation. Resonance is achleved by inparting a Doppler velocity to a radioactive source relative ta a Fixed sample. The transmission of the gama radiation through the glass sample is measured with a proportional counter. The 14.4-keV gamma radiation is selected using electronic discriminators, and the data are collected in a mulichanne? analyzer or mitrocomputer. Due to nonsymetric electric fields around the iron nuclei in glass samples at room temperature, the degeneracy of the excited $\pm 3 / 2$ nuclear spin state is partially removed, whith results in the

TABLE 1. Ferrous/Ferric Wet-Chemical Analysis of Sample 13

\begin{tabular}{lll} 
& Air & Argon \\
\cline { 2 - 2 } & 1.25 & 1.27 \\
1.21 & 1.28 \\
1.19 & 1.26 \\
1.21 & 1.17 \\
& & \\
Average & 1.22 & 1.24 \\
Standard deviation & 0.05 & 0.03
\end{tabular}


presence of two feaks in the spectra (referred to as a quadrupolemplit doublet). Their velocity separation is referred to as the atudrupole splitting (OS). The midpoint between the two peaks is referred to as the isomer shift (IS), which is standardized to a metalltc iron absorber. The QS and Is data are used to distingulsh ferrous from ferric iron and provide information con cerning the structural coordination of each ion.

A kanger scientiflc MS-900 Mossbauer spectrometer systeml a) was used for all transmission measurements. The measurements were made at roon temperature. A source consisting of 60 mCl of ${ }^{57} \mathrm{Co}$ diffused into a palladium matric was used. The glass powder was formed into a disk using an acrylic spray to prom duce an absorber concentration of $10 \mathrm{mg} F / \mathrm{cm}^{2}$ to represent an ideally thin absorber (Bancroft 1973). The spectrometer was operated in the constant acceleration mode using a sawtooth waveform to drive the velocity transducer at an increment of about $0.009 \mathrm{~mm} / \mathrm{s}$ channel. Moire interferometer data were collected in pairs and alternately with spectral data in the 1024 channels of menory for velocity callbration, although a natural iron foll standard was also used for this purpose. The spectra generally were collected over a 6 m to 20-h pertod. The data were transmitted to a $V A X-11 / 100$ computer $(b)$ for fitting and plotting. A nonlinear regression progran was written to include additive Lorentzian and Gausian components in the line shape, using the form of the equation presented in bowty and Lindsley (1973). A quadratic expression was also added to account for a potential nonlinearity in the background. An orthogonality matrix was incorporated (Bancroft et al. 1966) that pernits conm straints anong the fituting parameters to be imposed.

A convergence criterion for the goodness-ofmit parameter $\left(x^{2}\right)$ of $10^{-6}$ was generally achleved in six to eight iterations. For the 409 degrees of freedom in most spectra, $x^{2}$ at the $99 \%$ confidence limit was about 480 . Most spectra were fitud to one ferrous and one ferric quadrupole-split doublet with $x^{2}$ values near 450 or less indicating an acceptable fit. The components of the ferrous doublet were constrained to have the same intensity and widh. Similar constraints were made for the ferric peaks. Due to the asymetry reported for

(a) Ranger Scientific, Inc., Fort Worth, Texas.

(b) Ofgital Equipment Corporation, Maynard, Massachusetts. 
highly reduced samples, in which the low-velocity ferrous resonance develops greater inkensity than the broader nigh-velocity resonance, many studies fitced more than one ferrous doublet to the spectrun for example, Mysen, Virgo, and Seifert 1984). However, subordinate ferrous peaks were not fitted in more oxidized samples in those studies due to their low intensities relative to the tackground.

The samples considered in this sudy generally fall in this oxidized range due to oxidation state constraints imposed by the vitriffotion systen. Nevertheless, the impact of fitting additional ferrous peaks on the resutting Fit ratio were examined. Altering the line shape by Gassian addition was found wo be important in statistically optiming the fit of each spectrum and the resulting correlation with wet-chemistry data. The Mossbaver and wet-chemistry data are summarized in Table 2 .

\section{TABLE 2. Sumary of Mossbauer and Het-Chemistry data}

\begin{tabular}{|c|c|c|c|c|}
\hline \multirow[b]{2}{*}{ Samole } & \multirow[b]{2}{*}{ Composition(a) } & \multicolumn{2}{|c|}{ Ferrous/Total Iron } & \multirow{2}{*}{$\begin{array}{l}\text { Line Shape, } \\
\text { Lorentzian }\end{array}$} \\
\hline & & Mos sbauer & Wet-Cheruistry & \\
\hline 1 & Hanford & 0.14 & 0.11 & 95 \\
\hline 2 & Hanford & 0.00 & 0.00 & 90 \\
\hline 3 & Savannah River & $0.21(<0.01)$ & $0.15(<0.01)$ & $69(3)(0)$ \\
\hline 4 & Savannah River & $0.47(0.01)$ & $0.39(0.01)$ & $70(1)$ \\
\hline 5 & Savannah River & $0.54(0.01)$ & 0.45 & $60(7)$ \\
\hline 6 & West valley & 0.00 & 0.00 & 70 \\
\hline 7 & West valley & 0.00 & 0.00 & 75 \\
\hline 8 & West Valley & 0.25 & 0.19 & 63 \\
\hline 9 & West Valley & 0.34 & 0.31 & 64 \\
\hline 10 & West Valley & 0.46 & 0.39 & 61 \\
\hline 11 & West Valley & 0.60 & 0.53 & 68 \\
\hline 12 & 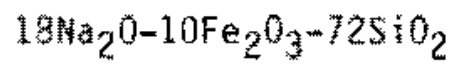 & 0.27 & 0.24 & 63 \\
\hline 13 & $18 \mathrm{Na}_{2} \mathrm{O}-10 \mathrm{Fe}_{2} \mathrm{O}_{3}-72510_{2}$ & 0.69 & $0.55(0.04)^{(d)}$ & 60 \\
\hline
\end{tabular}

(a) Savannah River, Hanford, and West Valley designations are simulated alkalimiron-borosilicate glasses.

(b) This Hanford glass contains iron as the only multivalent ion.

(c) Numbers in parentheses are standard deviations.

(d) Conbined data from Table 1 . 
RESULTS

The results from the Hossbauer spectroscopy and wet-chemistry investigathons are presented in this section.

Mossbauer Spectra

Three fitted transmistion Mossbauer spectra are presented in Figure 1 to Mustrate the effect of an increasing proportion of ferrous iron in these borosilicate glasses. The botton spectrun represents an early oxldized Hanford compostution collected from the pNi. pllot-scale ceraric melter (PSCM). It conm tains only one quadrupole-split doublet due to ferric iron, consistent with its wet-chemistry analysis (Table 2, Sample 2), with components naving equal intenstites that occur near 0 and $1 \mathrm{~mm} / \mathrm{s}$. The niddle spectum represents a West Valley glass melted from a liquid slurry in the faboratory. A sufficient amount of reducing compounds was included in the starting materials to produce a detectable ferrous iron peak. The upper spectrum represents a reduced Savannah River composition also collected from the Pscm. These spectra show the appearance of the broader ferrous peaks near 0.1 and 2 min/s. The isomer shifts, quadrupole splittings, and half-widths full-width at half of the maximum intensity) for the borosilicate glasses are $0.32( \pm 0.02), 0.93( \pm 0.02)$, and

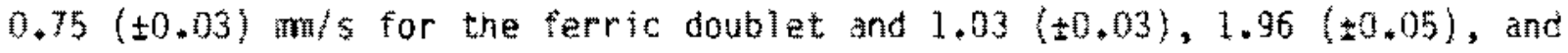
$0.96(40.11)$ mons for the ferrous doublet, respectively* These data are sirilar to those reported for the borosllicate glasses 5 tudied by Taragin and Eisenstein (1970). The lower velocity ferrous and ferric peaks closely overlap. leading to the increasing asymetry of the spectral profile with increasing ferrous iron content. This change in spectral protile was used to detemine ferrous/ferric ratios from the measured intensity data, as will be discusted in a later stction. The isomer shift and halfwidth of the ferric peaks for the silicate glass are smaller by about $0.07 \mathrm{~mm} / \mathrm{s}$ than for borosilicate glass. The nther parameters ara the same within error lints.

Line Shape

The effect of altering the line shape on the spectral analysis of the reduced Savannat River sample (FTI $=45 \%$ ) shown in the upper portion of Figure 1 is presented in Figure 2. The percentage of the Gaussian contribution 


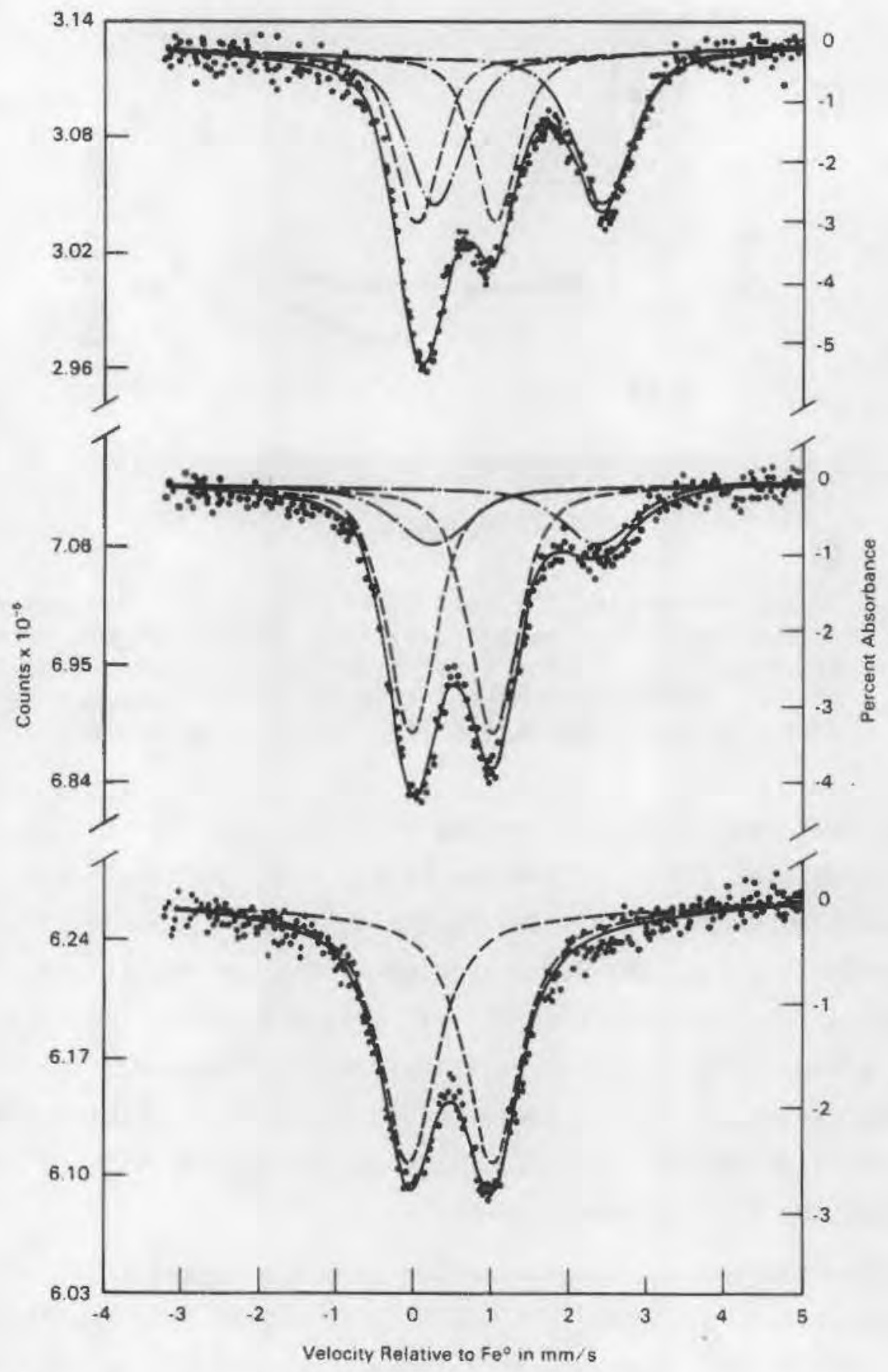

FIGURE 1. Mossbauer Spectra of Simulated Hanford (Sample 2, bottom), West Valley (Sample 8, middle), and Savannah River (Sample 5, top) Glasses Prepared at PNL. Ferric peaks (dashed) occur near 0 and $1 \mathrm{~mm} / \mathrm{s}$; and ferrous peaks (dot-dash), near 0.1 and $2 \mathrm{~mm} / \mathrm{s}$. The ferrous/total iron ratios from wet-chemistry analyses of these samples were $0.00,0.19$, and 0.45 , respectively. 


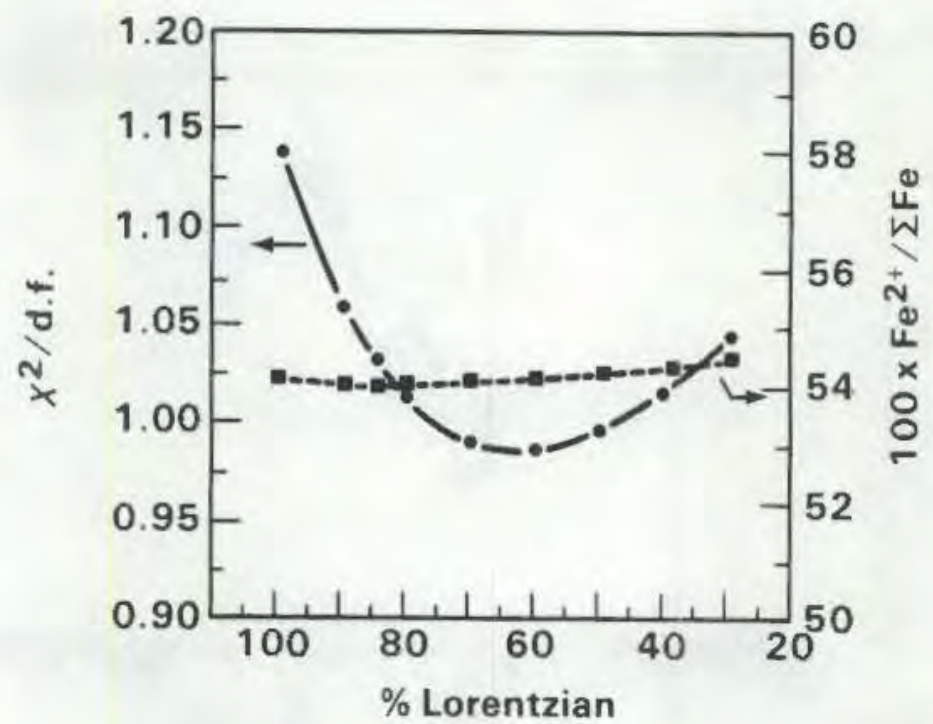

FIGURE 2. Effect of Varying the Peak Line Shape in the Mossbauer Spectrum of Sample 5, Showing a Statistical Optimum at $60 \%$ Lorentzian. The resulting ferrous/total iron ratio does not strongly depend on the line shape used for this relatively reduced sample. Two doublets were used in the fit; d.f. is the degrees of freedom.

included in each peak is plotted on the abscissa, and the resulting FTI ratio from the two-doublet fit is referenced to the right vertical axis. The resulting $\chi^{2}$ value from each fit, divided by the degrees of freedom, is referenced to the left vertical axis. The $99 \%$ confidence limit for the fit would occur at 1.18 on this axis. The resulting FTI ratio is relatively insensitive to line shape over a wide range for this relatively reduced sample. There is a significant improvement in the goodness-of-fit as the line shape becomes more Gaussian and is optimized at $60 \%$ Lorentzian. All of the fits in Figure 2 are acceptable at the $99 \%$ confidence level.

A similar analysis was performed for a more oxidized (FTI $=15 \%$ ) Savannah River sample (Figure 3). Sample 3 was also collected from the PSCM. Again, there is a significant improvement in the goodness-of-fit as the line shape becomes more Gaussian, which reaches a minimum at $70 \%$ Lorentzian and on $7 y$ increases slightly thereafter. This line shape is slightly greater than the one found for the more reduced sample described above. The resulting FTI ratio for Sample 3 (more oxidized) strongly depends on the line shape and nearly doubles from $100 \%$ to $30 \%$ Lorentzian. The spectrum of the oxidized Hanford 


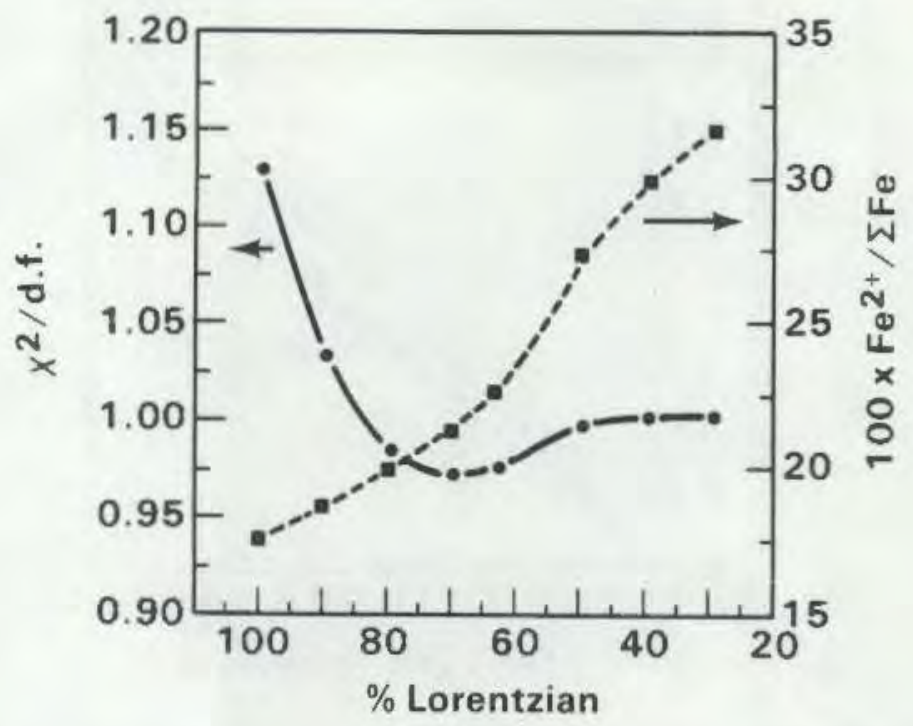

FIGURE 3. Effect of Varying the Peak Line Shape in the Mossbauer Spectrum of Sample 3, Showing a Statistical Optimum at About $70 \%$ Lorentzian. The resulting ferrous/total iron ratio strongly depended on the line shape for this relatively oxidized sample.

glass in Figure 1 is statistically optimized with a line shape having a $90 \%$ Lorentzian component. Thus, there appears to be a trend with more reduced samples having a greater Gaussian component in their line shape. However, there is considerable scatter in this correlation from the data in Table 2. Mossbauer/Wet-Chemistry Correlation

The Mossbauer spectrum for each sample was analyzed as a function of line shape, as in Figures 2 and 3 . The FTI ratio was obtained from the fit having the minimum $\chi^{2}$ value and used for correlation with wet-chemistry data (Figure 4). Line shapes ranged from 95\% Lorentzian for some oxidized samples to $60 \%$ Lorentzian for the most reduced samples. The data are summarized in Table 2. The trend of the data was linear with a correlation coefficient of 0.99. A linear regression of the data with and without constraining the intercept to intersect the origin led to the same result within error limits. Therefore, the regression was constrained to intercept the origin, which led to a slope of 0.83 . This result indicates that area ratios obtained from these Mossbauer spectra overestimated the FTI ratio by a factor of 1.2 (or the ferrous/ferric ratio by 1.5 ). This linear correlation would not be achieved for a fixed line shape among the samples studied (with the worst case being 


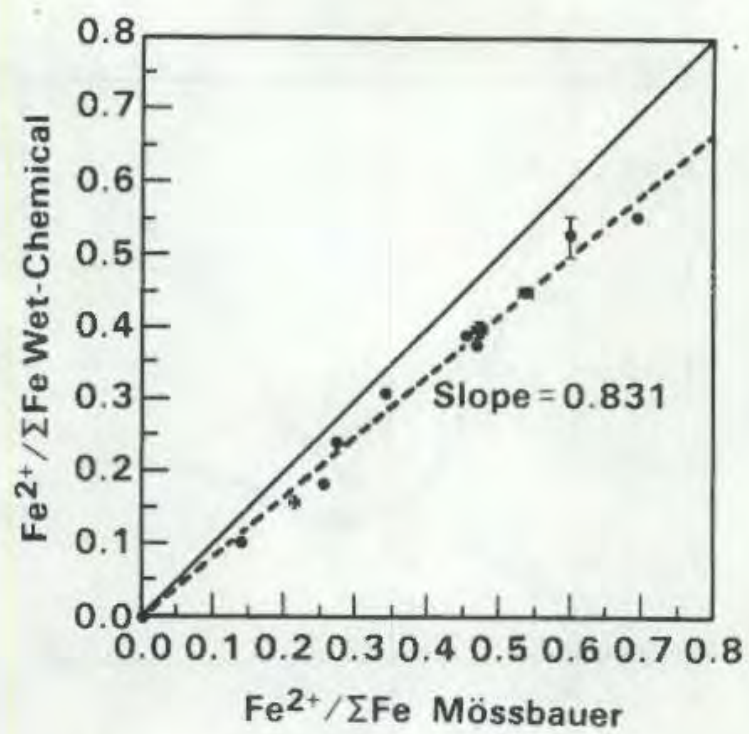

FIGURE 4. Correlation of Ferrous/Total Iron Ratios Determined by WetChemistry and Mossbauer Spectroscopy. The..slope of the regression line is 0.83 , indicating that Mossbauer area ratios overestimated the ferrous/total iron ratio in these glasses by 1.2. The correlation coefficient is 0.99 .

fully Lorentzian). As shown in Figures 2 and 3, the FTI ratios from the more reduced samples were relatively insensitive to line shape and, thus, will not affect their location in Figure 4. However, there are significant departures from the locations plotted in Figure 4 for the more oxidized samples as their 1 ine shape changed, as expected from Figure 3.

An important consideration of the relationship presented in Figure 4 is that it includes complex borosilicate waste glasses containing a variety of potentially interacting redox species, waste glasses that were prepared to contain iron as the only multivalent ion, and simple sodium-iron-silicate glasses. Nevertheless, these glasses describe a single linear correlation, suggesting that potential interactions between different multivalent species (for example, iron, cerium, chromium, and manganese) during sample digestion with the wetchemistry technique are not significant. It was further demonstrated that the effect of an oxidizing atmosphere during sample digestion did not affect the resulting FTI ratio (Table 1 ). Thus, the bias in Figure 4 is concluded to result from the use of area ratios from the Mossbauer method. 


\section{Additional Ferrous Peaks}

The spectral asymmetry that develops in the Mossbauer spectra of reduced glasses causes difficulty in computer fitting. Most workers interpret this pattern to result from a continuum of ferrous sites having different distortions in the glass structure and recognize that any fitting scheme is at best an approximation. For spectra fitted with more than two ferrous peaks, which peaks are paired to form a quadrupole-split doublet? Are the various area or half-width fitting constraints physically meaningful or simply mathematically useful? These uncertainties have led to several approaches. One approach is to fit the high-velocity region with two ferrous peaks and the low velocity region to one combined ferrous peak, thus leading to a positive relationship between IS and QS (Mysen and Virgo 1978; Mysen, Seifert, and Virgo 1980; Mysen, Virgo, and Seifert 1984). Others fit two ferrous doublets having nearly the same IS but different QS (Boon and Fyfe 1971, 1972). These different fitting schemes probably have a greater impact on structural interpretation than on the determination of the FTI ratio. Mysen, Virgo, and Seifert (1984) indicated that various fitting methods did not result in a change in the FTI ratio.

It therefore becomes important to evaluate whether the Gaussian broadening encountered in the two-doublet fits in this study contributes to the discrepancy with the wet-chemistry data. For this reason, the reduced Savannah River glass shown in Figure 1 was reanalyzed by adding a second ferrous doublet. The resulting fit is presented in Figure 5. The ferrous half-widths were constrained to be equal, and the equal area constraint was maintained for each doublet. The IS, QS, and half-width values determined for the ferric and ferrous doublets are $0.34,0.92$, and $0.76 \mathrm{~mm} / \mathrm{s} ; 1.06,2.12$, and $0.72 \mathrm{~mm} / \mathrm{s}$; and $1.13,1.15$, and $0.72 \mathrm{~mm} / \mathrm{s}$, respectively. The ferric parameters remain relatively unchanged compared with the two-doublet fit. This relationship was observed for all samples studied. The low-velocity ferrous peaks did not overlap in this fit, which is similar to those of Boon and Fyfe (1971, 1972). Including the second ferrous doublet decreased $\chi^{2}$ from 397 to 353 for 404 degrees of freedom. The $x^{2}$ value reached a minimum at a 1 ine shape that was $65 \%$ Lorentzian with little change in the FTI ratio, similar to Figure 2. The resulting FTI at $65 \%$ Lorentzian of $52.4 \%$ was the same, within error, as the 


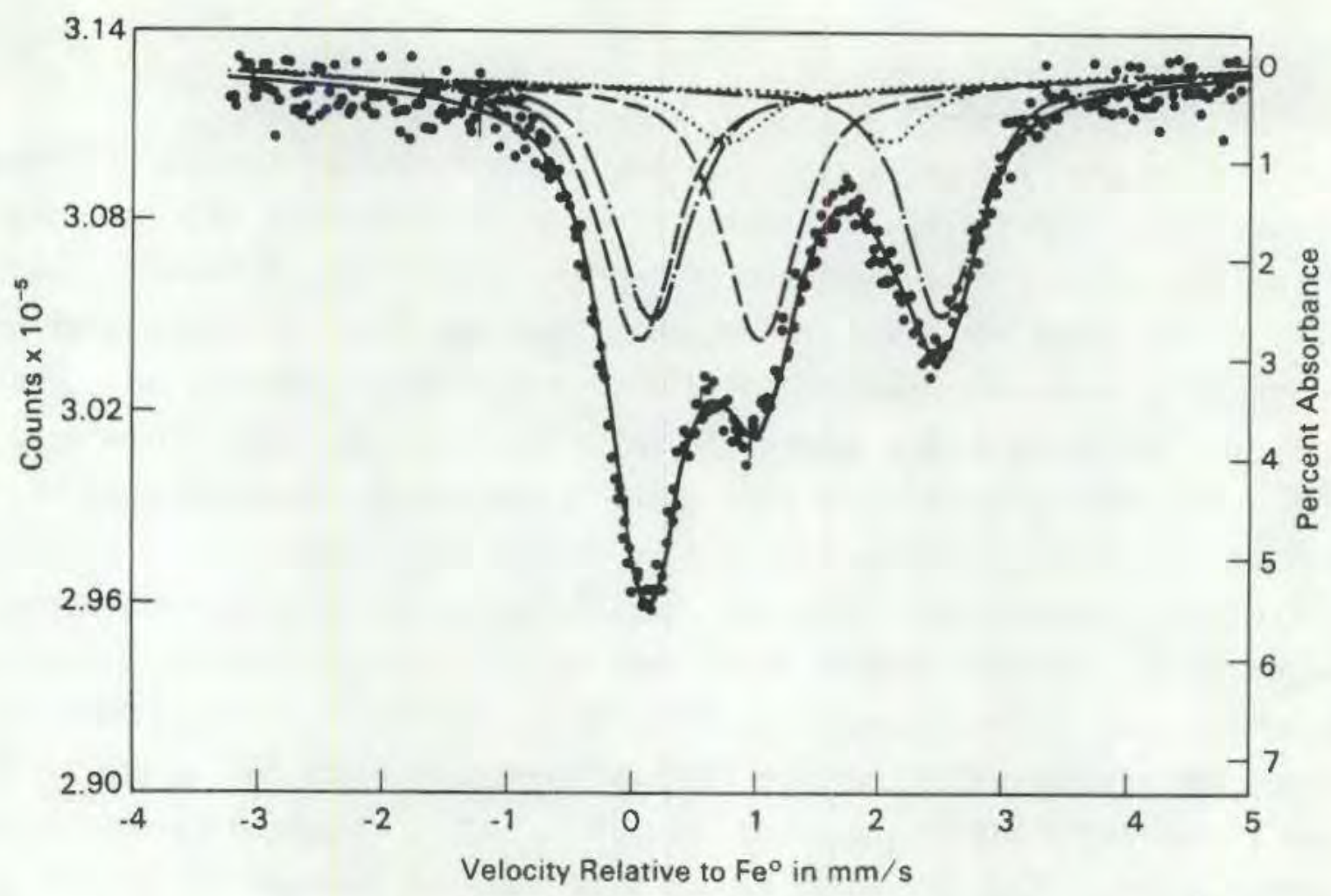

FIGURE 5. Mossbauer Spectrum of Sample 5 (Figure 1) Fitted with an Additional Ferrous Quadrupole-Split Doublet (dotted line). The resulting ferrous/total iron ratio from this fit of 0.52 is the same, within error, as the ratio from the fit in Figure 1 of 0.54 . Both area ratios are greater than the ratio of 0.45 determined from wetchemistry.

value obtained from the two-doublet fit of $53.6 \%$ (Table 2). Similar results were obtained for the reduced sodium-iron-silicate glass (FTI $=67 \%$ ), except that the peaks were narrower $(0.68$ to $0.70 \mathrm{~mm} / \mathrm{s})$ and the QS of the ferric doublet was smaller $(0.86 \mathrm{~mm} / \mathrm{s})$ than for the borosilicate glasses. Therefore, it is concluded that the two-doublet fits used for the correlation presented in Figure 4 did not induce the bias in the Mossbauer data.

Correlation with Measured Intensity Data

The change in the spectral profile with an increasing proportion of ferrous iron can be used to determine the ferrous/ferric ratio from the measured intensity data. The measured intensities were extracted from the same channels in each computer data file. The background intensity was obtained from a channel near $-3 \mathrm{~mm} / \mathrm{s}$. Intensities near $0,0.8$, and $2.1 \mathrm{~mm} / \mathrm{s}$ were extracted to 
represent the combined ferrous and ferric peak, the ferric peak, and the ferrous peak, respectively. The peak intensities were subtracted from the background intensity. Various intensity ratios were then determined and plotted (Figure 6 ). The $\mathrm{I}^{1} / \mathrm{I}^{0}$ ratio represents the intensity ratio of the peaks near 1 and $0 \mathrm{~mm} / \mathrm{s}$, which should approach unity as the ferrous/ferric ratio decreases to zero. The trend of these data is linear and extrapolates to nearly unity at a ferrous/ferric ratio of zero. The two samples having the lowest ferrous/ ferric ratios did not appear to fall in the linear trend defined by the other samples and were excluded from the regression line plotted in Figure 6 . The $I^{2} / I^{1}$ ratio represents the intensity ratio of the high-velocity ferrous and ferric peaks, which should approach zero as the ferrous/ferric ratio decreases to zero. A linear correlation is also achieved for these data, which extends close to zero in Figure 6 . The sample having the largest ferrous/ferric ratio was excluded from this linear regression because it did not appear to fall in the trend defined by the other data. The correlation coefficients for each set of data in Figure 6 are from 0.97 to 0.98 . The range of acceptable ferrous/ ferric ratios for the vitrification process is estimated to occur between 0.1

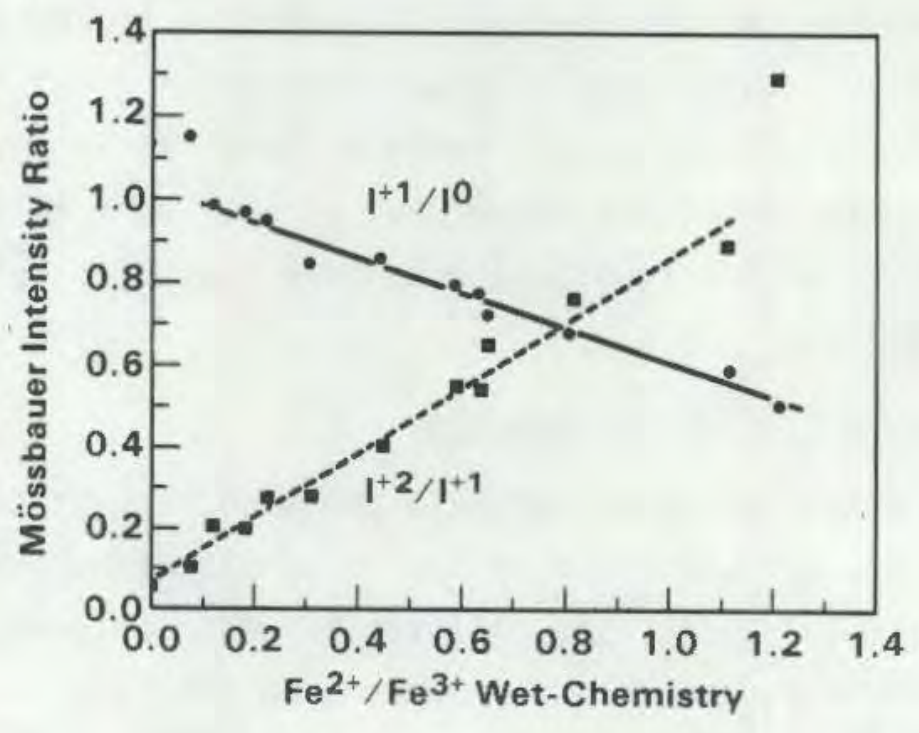

FIGURE 6. Correlation of Mossbauer Intensity Data with the Ferrous/Ferric Ratio Determined from Wet-Chemistry. I $I^{1 / I^{0}}$ is the backgroundcorrected intensity ratio of the ferric peak near $1 \mathrm{~mm} / \mathrm{s}$ and the combined ferrous and ferric peak near $0 \mathrm{~mm} / \mathrm{s}$. $\mathrm{I}^{2} / \mathrm{I}^{1}$ is the intensity ratio of the ferrous peak near $2 \mathrm{~mm} / \mathrm{s}$ and the ferric peak at $1 \mathrm{~mm} / \mathrm{s}$. 
and 0.5 (Goldman and Brite 1985; Goldman, Brite, and Richey 1985). Therefore, either correlation in Figure 6 would be acceptable for control purposes, al though the $\mathrm{I}^{2} / \mathrm{I}^{1}$ correlation appears to be more consistent for these oxidized samples. The regression equations shown in Figure 6 are:

$$
\begin{aligned}
& \mathrm{Fe}^{2+} / \mathrm{Fe}^{3+}=-2.25\left(\mathrm{I}^{1} / \mathrm{I}^{0}\right)+2.34 \\
& \mathrm{Fe}^{2+} / \mathrm{Fe}^{3+}=1.25\left(\mathrm{I}^{2} / \mathrm{I}^{1}\right)-0.07
\end{aligned}
$$

Figure 6 shows that background-corrected, measured-intensity data at three velocity locations can be used to determine the ferrous/ferric ratio in these glasses, thereby eliminating the need for mathematically complex fitting procedures and the need for a large computer. Since only three velocity locations are required to obtain the ferrous/ferric ratio (rather than scanning the entire spectral region with typically 1024 channels of memory), a considerable savings in time becomes possible. For example, the microcomputer that controls the Mossbauer system could be used with the laser interferometer to drive the velocity transducer to the three velocity locations of interest, rapidly collect the data, and use the calibrations presented in Figure 6 to output a ferrous/ferric ratio. Using this approach and faster counting electronics, it is estimated that analytical results could be obtained in less than $1 \mathrm{~h}$. This potential would serve the longer-range goal of this work to provide a simple analytical procedure with a rapid response time that will better support the vitrification process.

Mossbaver Testing of Radioactive Glasses

The results presented above indicate the viability of the Mossbauer method for the analysis of ferrous/ferric ratios in simulated nuclear waste glasses. At this point, its utility for the analysis of radioactive glasses has not been demonstrated. Mossbauer spectroscopy depends on the resonant absorption of relatively low energy $(14.4-\mathrm{keV})$ gamma rays generated by the radioactive ${ }^{57} \mathrm{Co}$ source in the instrument. This source typically has an activity of about $50 \mathrm{mCi}$. The experiment is complicated for radioactive glass samples because they also emit a variety of radiations (for example, beta from ${ }^{90} \mathrm{Sr}$ and gamma 
from ${ }^{137} \mathrm{Cs}$ ) into the gas-filled proportional counter. The net effect of these processes is to substantially increase the background intensity, which diminishes the signal/noise ratio of the desired resonant peaks in the Mossbauer spectrum. For example, a reasonable estimate of the combined activity from Cs and $\mathrm{Sr}$ in West Valley and Savannah River glasses at their expected waste loadings will probably be greater than $0.1 \mathrm{Ci} / \mathrm{g}$. To achieve an acceptable concentration of iron in the glass sample in a Mossbauer experiment of 7 to $10 \mathrm{mg}$ $\mathrm{Fe} / \mathrm{cm}^{2}, 0.3$ to $1.0 \mathrm{~g}$ of glass are generally used. Thus, the sample may have an activity level of 30 to $100 \mathrm{mCi}$ from $\mathrm{Cs}$ and $\mathrm{Sr}$, compared with $50 \mathrm{mC} i$ from the Co source. Although options exist to minimize some of these problems (such as beta shielding, reducing the amount of glass used, and better collimation of the cobalt source), the above calculations suggest that the background problem will be a significant factor in the Mossbauer analysis of radioactive glass.

In order to evaluate this problem, a shielded container was designed and constructed for the Mossbauer spectrometer for testing radioactive glasses in a hot cell environment (Figure 7). The double-walled container is made from 1/4-in. steel plate and filled with $2 \mathrm{in}$. of lead. The main chamber contains the velocity drive, laser interferometer, Co source, and beam collimator. The electrical connections pass through the container wall at an angle to minimize direct radiation penetration. The detector is separated from the source and sample by a wall containing $1.5 \mathrm{in}$. of lead. The wall is slotted to hold the sample in the beam and has an aperture to pass the radiation to the detector. The lid is placed over the bottom section to seal the spectrometer. The entire contained unit can be moved by crane using the slotted connections shown on the sides of the container.

The sample is ground in a hot cell and weighed. The appropriate amount is placed in a Plexiglas (a) mounting plate (also shown in Figure 7). This plate is made with three $1 / 16-i n$. Plexiglas plates in a sandwiched configuration. The middle plate has a 1.125-in. diameter hole drilled in it that is aligned with the axis of the beam when it is inserted into the sample slot of the lead container. This plate is glued to the solid bottom Plexiglas plate. The

(a) Registered tradename of the Rohm and Haas Company, Philadelphia, Pennsylvania. 


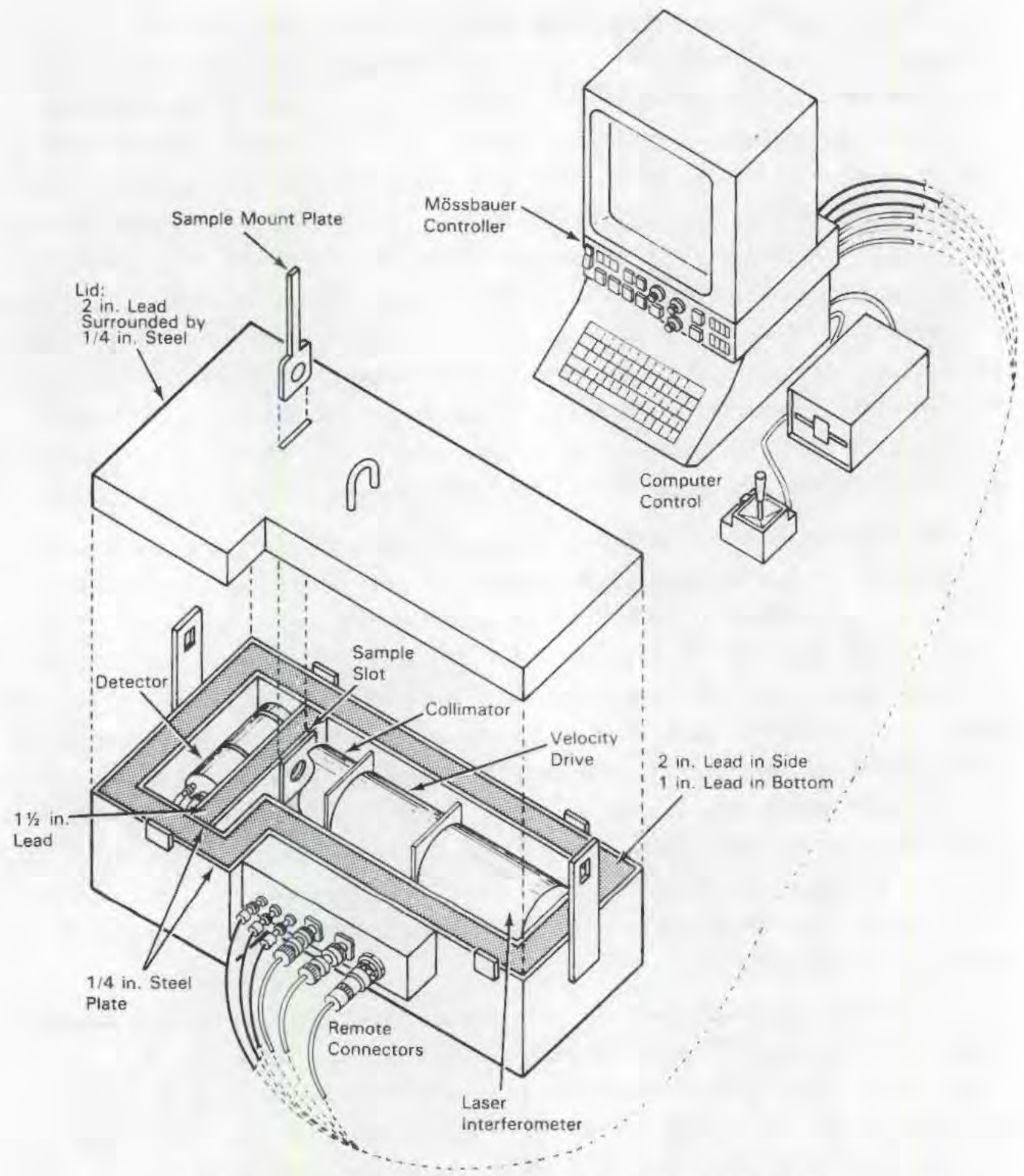

FIGURE 7. Mössbauer System for Radioactive Samples 
sample is evenly spread into this cavity and secured with an acrylic spray. The top Plexiglas plate is then glued, thereby sealing the sample in Plexiglas for transport to the spectrometer.

Three samples were prepared and analyzed. The first glass contained $U$ and Th and was melted from a liquid feed in a clay crucible. The waste fraction was made to simulate West Valley waste, but it included $U$ and Th. The final glass composition is referred to as WV183, which is a developmental glass used at PNL. This glass contains $44.6 \mathrm{wt} \% \mathrm{SiO}_{2}, 12.7 \mathrm{wt} \% \mathrm{~B}_{2} \mathrm{O}_{3}$, and $15.0 \mathrm{wt} \% \mathrm{Na}_{2} \mathrm{O}$ as the major glass formers. It also has $12.3 \mathrm{wt} \% \mathrm{Fe}_{2} \mathrm{O}_{3}, 0.6 \mathrm{wt} \% \mathrm{uO}_{2}$, and $3.6 \mathrm{wt} \%$ $\mathrm{ThO}_{2}$ contributed by the waste. Sodium was included in the feed as sodium oxalate, and additional sugar was used to produce a measurable ferrous/ferric ratio. Wet-chemical analysis indicated 0.15 wt\% as $\mathrm{Fe}^{+2}$, resulting in a ferrous/ferric ratio of 0.02 . The Mossbauer spectrum of this sample is presented in Figure 8 , which clearly shows the ferrous peaks near 0.1 and $2 \mathrm{~mm} / \mathrm{s}$

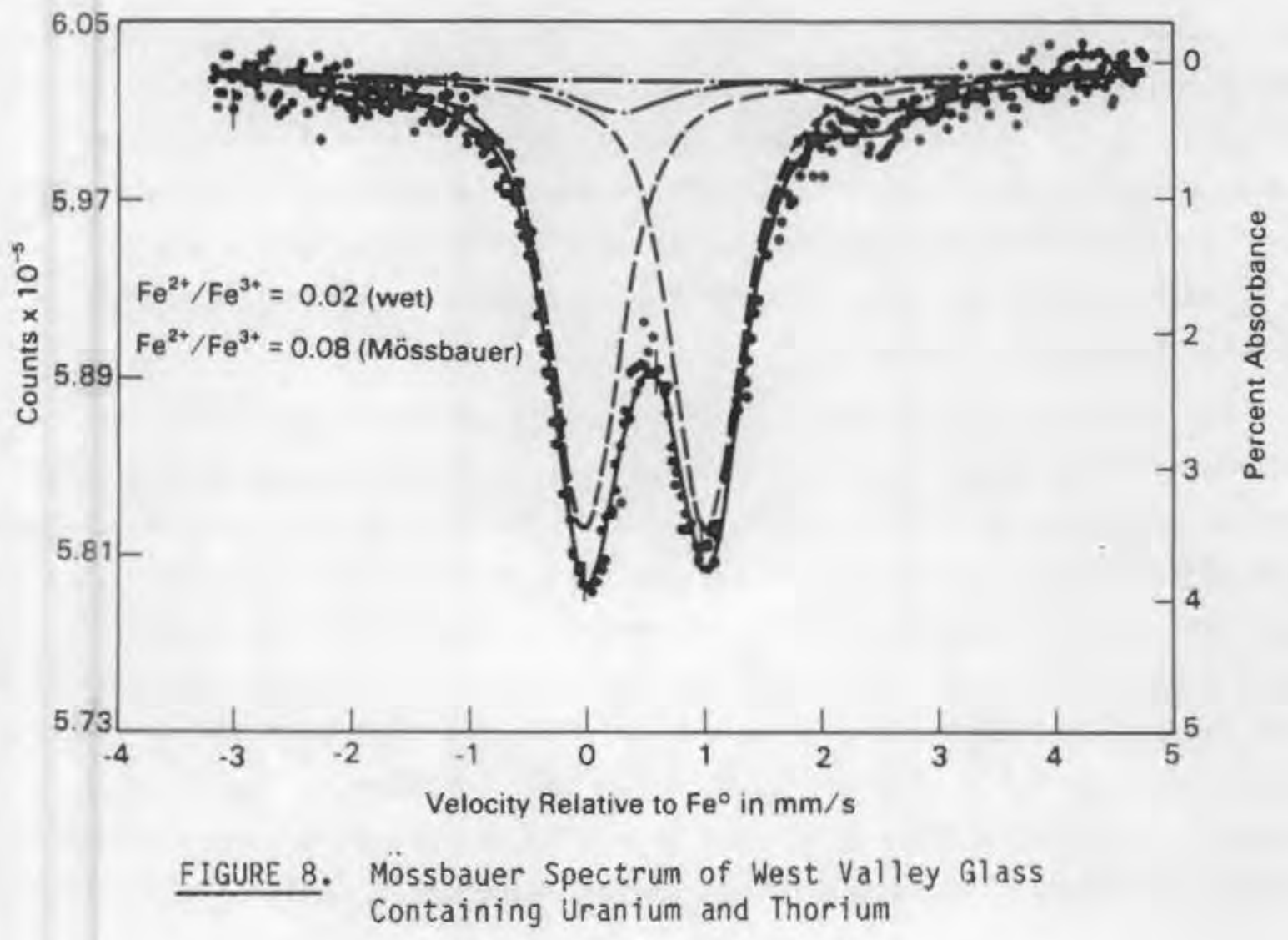


and a ferrous/ferric ratio of 0.08 . Therefore, the presence of $U$ and Th did not significantly interfere with the analysis of the ferrous/ferric ratio in this oxidized sample.

The second sample analyzed was the fully radioactive ATM-5 borosilicate glass described by Mellinger and Daniel (1983, Table 5). This glass was based on the 76-68 glass composition for repository development tests in the MCC program and was estimated to have a total activity level at that time of about $0.5 \mathrm{Ci} / \mathrm{g}$ from ${ }^{137} \mathrm{Cs}$ and ${ }^{90} \mathrm{Sr}$ in roughly equal proportions. About $1.2 \mathrm{~g}$ of this sample was ground in the hot cell and placed in the Plexiglas sample holder. Prior to placing the shielded spectrometer in the air lock, a spectrum of $0.0005-i n$. thick natural iron foil standard was analyzed in the closed, shielded spectrometer, which verified that the instrument was operating properly. The shielded spectrometer was then placed in the air lock. The sample was removed from the adjacent hot cell and inserted into the spectrometer. The background counting rate increased significantly. The pulse-height (energy) spectrum became featureless after the sample was inserted. In contrast, the 14.4-keV gamma peak can be clearly observed with a nonradioactive sample in the spectrometer in the pulse-height spectrum. The settings of the electronic discriminators that were used to select the 14.4-keV gamma prior to the experiment with the foil were left in those positions for the analysis of the radioactive sample. Resonant peaks were not detected after several hours of counting in the Mossbauer mode of the spectrometer, which was attributed to the high background activity.

For the final experiment, the ATM-5 sample was remelted with a specially prepared frit in a ratio of 4 parts frit to 1 part ATM-5 to produce a glass similar to recent West Valley compositions. The frit had an analyzed composition of $57.7 \% \mathrm{SiO}_{2}, 11.1 \% \mathrm{~B}_{2} \mathrm{O}_{3}, 11.9 \% \mathrm{Na}_{2} \mathrm{O}, 6.1 \% \mathrm{Li}_{2} \mathrm{O}$, and $13.4 \% \mathrm{Fe}_{2} \mathrm{O}_{3}$. The resulting glass is estimated to have a major oxide composition of $54.2 \% \mathrm{Si}_{2}$, $10.8 \% \mathrm{~B}_{2} \mathrm{O}_{3}, 13.2 \% \mathrm{Na}_{2} \mathrm{O}, 4.9 \% \mathrm{Li}_{2} \mathrm{O}$, and $12.3 \% \mathrm{Fe}_{2} \mathrm{O}_{3}$. The $\mathrm{Sr}$ and $\mathrm{Cs}$ activity was thus reduced by a factor of five. In addition, the Mossbauer sample was prepared with only $0.5 \mathrm{~g}$ of glass to minimize the radiation emitted into the detector. Additional Plexiglas beta shielding was placed between the sample and the detector. The instrument parameters were again verified with the iron 
foil, except this time the foil was placed in a separate Plexiglas holder and inserted into the closed container in the air lock. The subsequent analysis of the new glass containing 20\% ATM-5 in the Mossbauer spectrometer again produced a featureless spectrum after $5 \mathrm{~h}$ of counting.

These results suggest that the Mossbauer method does not appear to be a viable analytical method for the measurement of ferrous/ferric ratios in radioactive glasses containing beta- and gamma-emitting radionuclides. This does not imply that additional modifications cannot be made to reduce the background problem to a level where a spectrum can be measured, such as using less sample, a stronger source, and combining a larger solid angle between the sample and detector with better collimation of the 14.4-keV beam. However, since other methods are available, such as wet-chemistry and ion chromatography, it is felt that they may be better suited for ferrous/ferric analyses in a hot cell environment.

\section{CONCLUSIONS}

The conclusions from this work can be summarized as follows:

- A linear correlation for FTI ratios determined by wet-chemistry and Mossbauer analyses was established using area ratios from fitted Mossbauer spectra after each spectrum was statistically optimized for the peak line shape. Fitting additional ferrous peaks did not alter this relationship.

- Area ratios determined from the Mossbauer spectra overestimated the FTI ratio by a factor of 1.2 . The wet-chemistry data appear to be correct and were not biased by an oxidizing atmosphere during sample digestion or by the presence of other multivalent ions in the glass.

- Measured intensity data at three velocity locations, one representing the background and two representing the ferric and ferrous resonant peaks, can be used to quantitatively measure the ferrous/ferric ratio in these complex glasses. This potential could lead to a new 
generation of analytical Mossbauer systems that could significantly decrease the data collection time and eliminate the need for complex spectral fitting.

- The Mössbauer technique can readily analyze waste glasses containing $U$ and Th; but tests with glasses containing beta- and gamma-emitting radionuclides $\left({ }^{137} \mathrm{Cs}\right.$ and $\left.{ }^{90} \mathrm{Sr}\right)$ were unsuccessful, suggesting that other methods should be pursued for ferrous/ferric analysis of fully radioactive glasses. 
It became clear early in the characterization of ferrous/ferric ratios that there was a pronounced difference in the color of oxidized and reduced waste glasses in powder form. Glasses lacking ferrous iron were generally a light tan color, whereas glasses with a measurable ferrous/ferric ratio were gray and became darker at larger ratios. This observation appeared to be obscured as the chromium content in the glass increased. The color change was readily observed for the WV199 composition containing $0.22 \mathrm{wt} \% \mathrm{Cr}_{2} \mathrm{O}_{3}$ but was difficult to detect for the WV182 composition containing 0.66 wt $\mathrm{Cr}_{2} \mathrm{O}_{3}$. There was essentially no perceptible change in color in recent Hanford glass (containing greater than $\left.1 \mathrm{wt} \% \mathrm{Cr}_{2} \mathrm{O}_{3}\right)$. Thus, it is possible to quantitatively measure the color of the glass powder from its reflectance properties using conventional colorimetry analysis. If this is proven to be a viable approach, then adaptation to a hot cell environment would be somewhat easier than for other methods because video cameras and optical fibers could be used to lessen radiation exposure.

\section{COLORIMETRY}

A brief discussion of colorimetry is required before discussing the color analysis results. Color analysis is used extensively in industry for quality control, mixing of pigments, etc. Computerized commercial colorimeters are available for most applications. Reflectance measurements are taken by such instruments for opaque samples, such as the highly absorbing nuclear waste glasses. Such samples will have their own characteristic spectrum over a wavelength from 380 to $780 \mathrm{~nm}(0.38$ to $0.78 \mu \mathrm{m})$, which covers the complete visible spectrum. The reflectance value at each wavelength is multiplied by a standard value for a selected type of illuminant source from published tables (Bamford 1977). This product at each wavelength is then multiplied by the published $x^{\prime}$, $y^{\prime}$, or $z^{\prime}$ tristimulus values, each representing an internationally accepted primary visual stimulus (for example, for green, blue, and red, respectively). The products of these multiplications at each wavelength are summed over the wavelength range specified above to arrive at values for $X, Y$, and $Z$. These 
values are then normalized so that they add up to unity, thus resulting in chromaticity, or color coordinate values, $x, y$, and $z$. In summary:

$$
\begin{aligned}
& \left.X=\operatorname{sum}[(\text { illuminant }) \times \text { (sample }) \times\left(x^{\prime} \text { tristimulus }\right)\right] \text { over } 380 \text { to } 780 \mathrm{~nm} \\
& Y=\operatorname{sum}\left[(\text { illuminant }) \times(\text { sample }) \times\left(y^{\prime} \text { tristimulus }\right)\right] \text { over } 380 \text { to } 780 \mathrm{~nm} \\
& Z=\operatorname{sum}\left[(\text { illuminant }) \times(\text { sample }) \times\left(Z^{\prime} \text { tristimulus }\right)\right] \text { over } 380 \text { to } 780 \mathrm{~nm}
\end{aligned}
$$

$$
\begin{aligned}
& x=\frac{X}{(X+Y+Z)} \\
& y=\frac{Y}{(X+Y+Z)} \\
& z=\frac{Z}{(X+Y+Z)}
\end{aligned}
$$

Since only two values are required to characterize the sample, the $x$ and $y$ chromaticity values are generally plotted. Figure 9 shows a color chart for a WV199 glass sample having a ferrous/ferric ratio of zero. The curve is referred to as a color locus. Points that lie on this curve have a pure color, such as a monochromatic filter. The square represents the value of the selected illuminant, which in this case is the 06400 illuminant representing standard daylight $(x=0.3138 ; y=0.3309)$. A line is drawn that connects the illuminant to the locus (at the solid circle) and passes through the sample point (open circle). The wavelength indicated by this intersection on the color locus is referred to as the dominant wavelength, which for this sample is near $580 \mathrm{~nm}$ (yellow). The ratio of the distance from the illuminant to the sample $(x)$ divided by the distance between the illuminant and the locus ( $y$ ) is referred to as spectral purity. It represents the amount of white light (illuminant) that is mixed into the pure color (locus). Thus, this sample has a major portion of its yellow color diluted with white light, which means that there is a considerable mixture of other colors in its appearance.

\section{EXPERIMENTAL METHODS}

The ferrous/ferric ratios of finely ground glass powders were characterized using wet-chemistry and then packed into small glass vials. A reflectance 


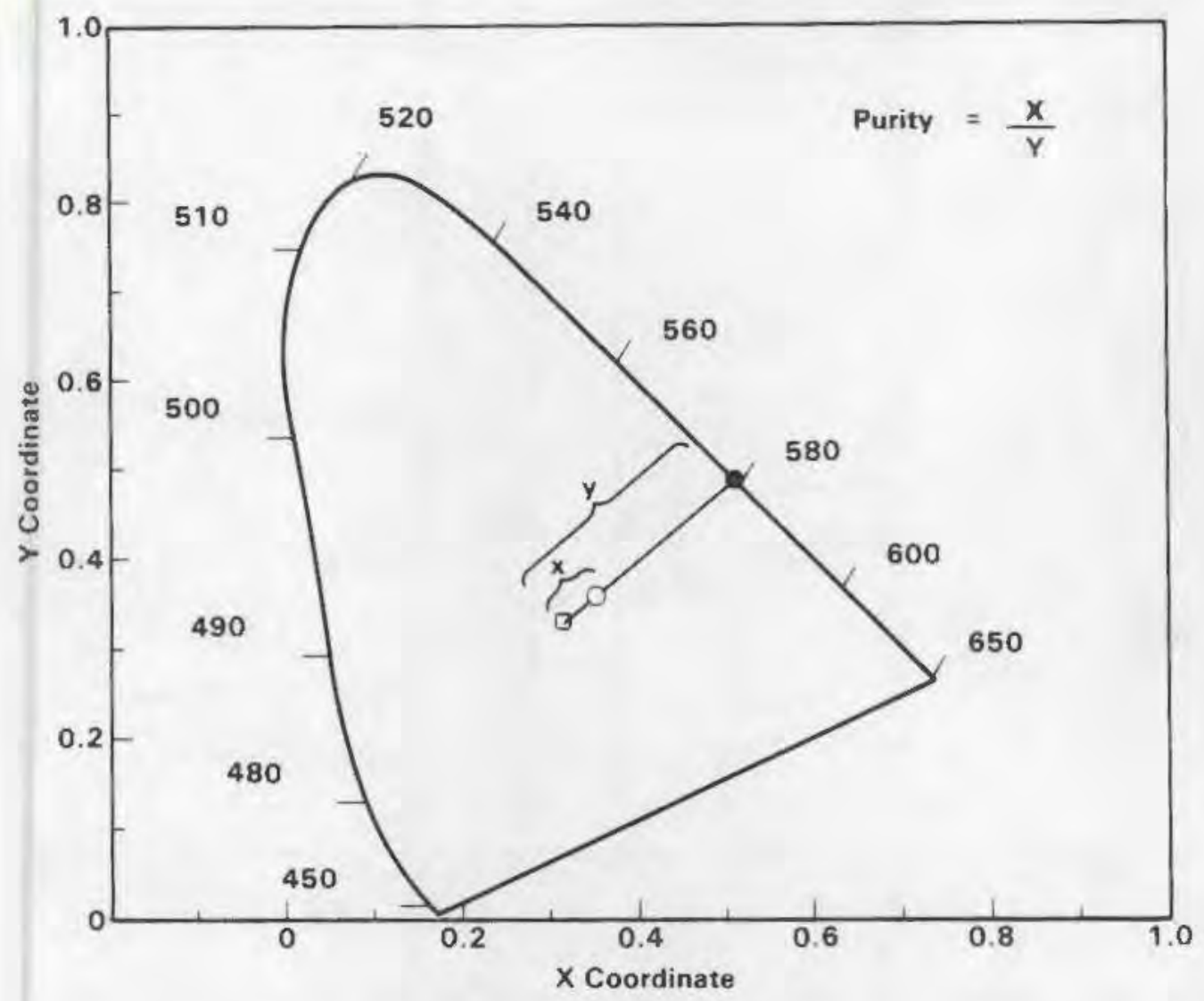

FIGURE 9. Color Analysis of Glass Powder of an Oxidized Simulated West Valley Glass

spectrum was taken over the 380- to $780-n m$ range at $10-n m$ intervals using a diffuse reflectance integrating sphere coated with barium sulfate in a UV-VIS-NIR spectrometer. Appropriate white and black standards were used as the 0 and $100 \%$ reflectance values. The chromaticity values were determined as described above. It was thought that reproducibility could be significantly improved if the powders were pressed into self-supporting disks, rather than being packed into vials.

\section{RESULTS}

The results for two West Valley compositions are presented in Figure 10. Spectral purity is compared against the ferrous/ferric ratio. The low chromium sample (WV199) shows a strong decrease in spectral purity as the ferrous/ferric ratio increases to a value near 0.5 , and then a relatively flat trend for more 

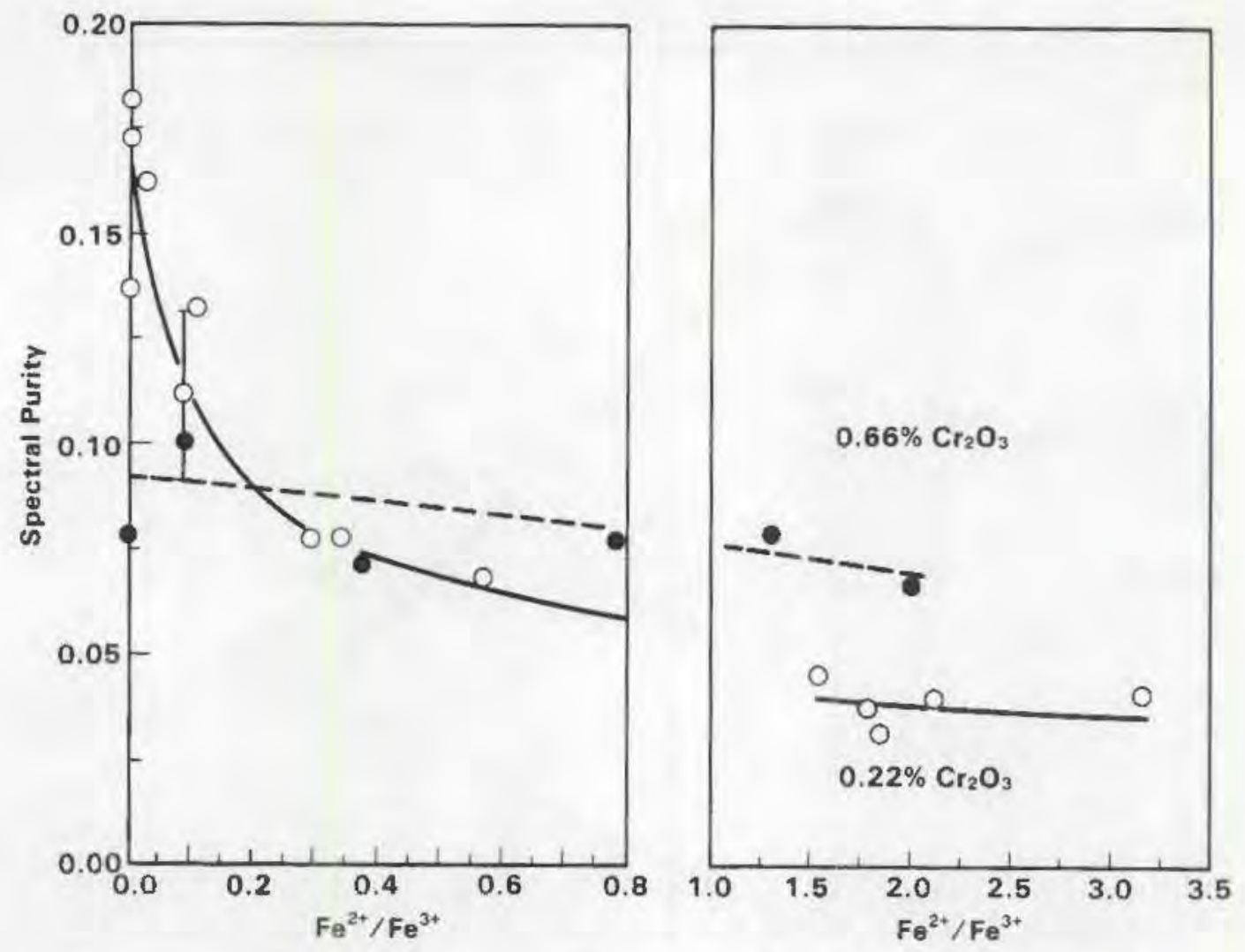

FIGURE 10. Effect of Redox on the Color of Simulated West Valley Glass

reduced samples. Thus, the major change occurs in the ferrous/ferric range that is reasonable for process control to prevent foaming and metal precipitation.

For the similar study with the WV182 glass, the additional chromium obscured the trend described above, making this approach not viable for high chromium wastes, such as the current Hanford waste. Since inductively coupled plasma emission (ICP) spectrometry compositional data will be available for the feed in the feed tank and possibly for some glass collected from the vitrification system, the amount of chromium will be known. Thus, its impact on the color analysis approach may be estimated with further work (i.e., different curves for different amount of chromium). However, this complication will clearly impair the precision of the method. 


\section{CONCLUSIONS}

Due to interference from chromium, this method may not be as precise as the other methods. However, it may be useful as a screening tool to determine if a subsequent ferrous/ferric analysis is required. 

Tests were conducted at PNL and the Dionex Corporation, Sunnyvale, California, to determine the feasibility of analyzing ferrous/ferric ratios by ion chromatography. As shown in Figure 11 (a sample spectrum provided by Dionex), $\mathrm{Fe}^{+2}$ and $\mathrm{Fe}^{+3}$ can be analyzed directly and a ratio can be obtained by direct comparison of the calibrated peak heights. The system consisted of a

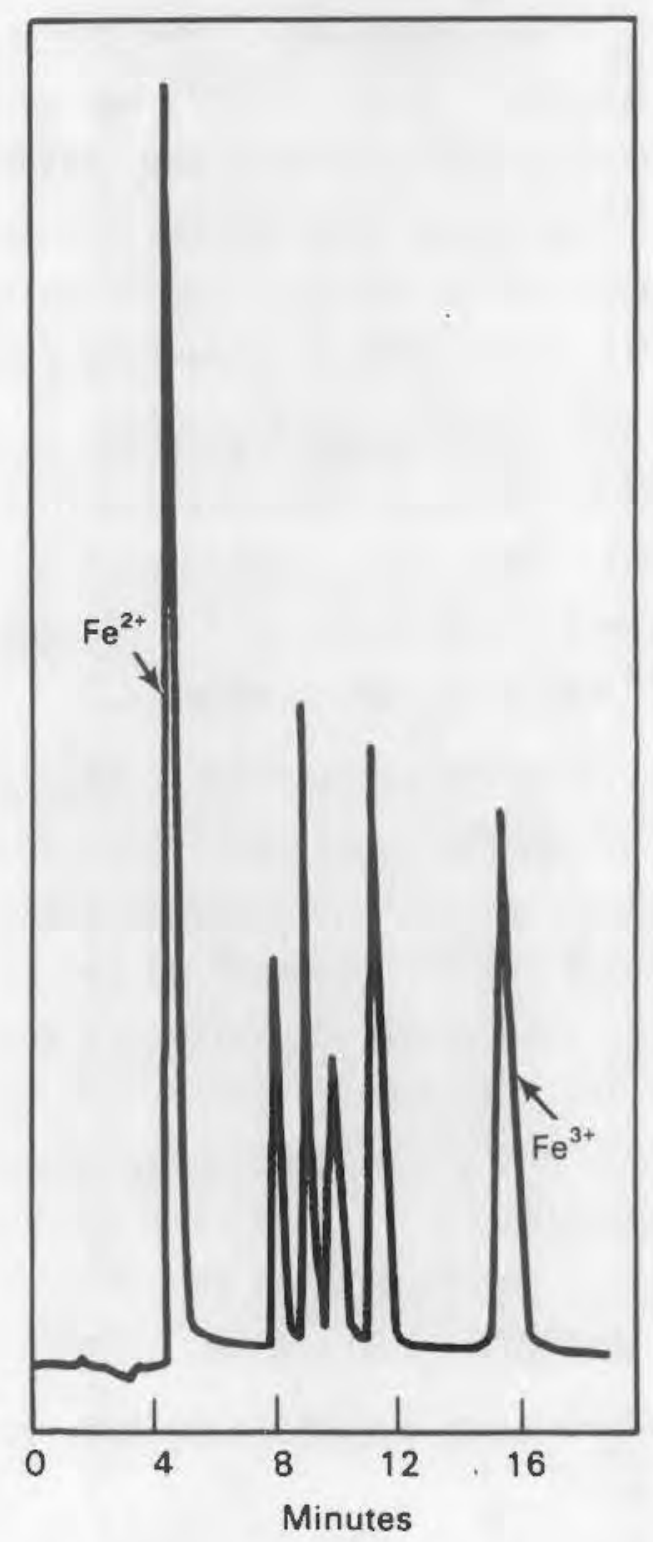

FIGURE 11. Separation of Transition Metals Using HPIC-CS5 Separator Column (information supplied by the Dionex Corporation) 
2000 series ion chromatograph with the post-column reactor and UV/VIS detector options. The analytical column was the HIC-CS5. The system can analyze up to about 20 heavy and transition metals and can separate and identify the different valence states.

\section{RESULTS}

For these analyses, the appropriate test conditions were set up and all elements and columns were degassed. When the system was stabilized, several standards were analyzed. It was determined that the detection 1 imit for $\mathrm{Fe}^{+2}$ was about $0.1 \mathrm{ppm}$; the detection limit for $\mathrm{Fe}^{+3}$ was even more sensitive. This $\mathrm{Fe}^{+2}$ detection limit can be achieved even in the presence of $20 \mathrm{ppm} \mathrm{Fe}+3$ with no interferences, which corresponds to a ferrous/ferric ratio of 0.005 . Although testing was stopped at $20 \mathrm{ppm} \mathrm{Fe}{ }^{+3}$ due to lack of time, higher levels would probably be possible, resulting in a lower ferrous/ferric ratio.

While it is possible to quantify $\mathrm{Fe}^{+2}$ at these detection levels, it is not possible to quantify $\mathrm{Fe}^{+3}$ in the same analyses due to the nonlinear response of $\mathrm{Fe}^{+3}$ above a few parts per million. A simple dilution of the concentrated solution will yield a direct analysis of $\mathrm{Fe}^{+3}$. However, due to time constraints, no further $\mathrm{Fe}^{+3}$ analyses were completed.

Two dissolutions of the WV202 composition (internal PNL working standard for analyses of the ferrous/ferric ratio) were tested: 1) with phenanthrolene and an adjusted $\mathrm{pH}$ of 3.4 and 2) without phenanthrolene and without $\mathrm{pH}$ adjustment. After the final solutions were brought to the required dilution volume $(100 \mathrm{~mL})$, they were poured into $25-\mathrm{mL}$ scintillation vials leaving $1 \mathrm{~mL}$ of air above the solution. The analyses showed little $\mathrm{Fe}^{+2}$ in Solution 1 even though the color was still very intense. In Solution 2, however, there was an abundant amount of $\mathrm{Fe}^{+2}$ in solution, indicating that the phenanthrolene complex removed $\mathrm{Fe}^{+2}$ from solution, thereby preventing its analysis by ion chromatography. Therefore, the Solution 2 was used as follows:

- add $0.5 \mathrm{~mL} \mathrm{H}_{2} \mathrm{SO}_{4}$ and mix with powder in an open atmosphere

- add $1.5 \mathrm{~mL} \mathrm{HF}$ and mix

- add $25 \mathrm{~mL} 4 \%$ boric acid

- add $10 \mathrm{~mL}$ KHP and $2 \mathrm{~mL} \mathrm{NH_{4 }}$ OH 
- transfer to flask and dilute to volume

- analyze by ion chromatography.

Quantituction of $\mathrm{Fe}^{+2}$ was obtained by comparing the peak heights to known liquid standards. Two $\mathrm{Fe}^{+2}$ standards were prepared: one by reduction of Fe $\mathrm{F}^{+3}$ wh hydroquinone and one by dissolution of $\mathrm{FeCl}_{2}$ in $2 \mathrm{HCL}$. Both standards nere within 3 of each other. Results of the fe $e^{+2}$ analyses are presented in Table 3. With additional development, $\mathrm{Fe}^{+3}$ would be directly analyzed by ion chromatography instead of the analysis of total ifon by the ICP technique as was done in this study.

\section{conclusions}

The results of this feasibility study show that with further davelopment ion chromatography may become a useful analytical method for ferrous/ferric analysis. Its similarity to the ICp procedure, which has been adapted for use with fuly radioactive samples at PNl., suggests that it could also be adapted for such samples. Therefore, th is recommended that inn chromatography be fully explored.

IABLE 3. Results of lon Chromatography (IC) Analysis of the Ferrous/ferric latio

$$
\begin{gathered}
\text { Theoretical Total Fe Calculated } \\
\text { Fe+2/Fe+3 Glass, IC Analyzed by ICP, Fe+3 by lce }
\end{gathered}
$$

\begin{tabular}{|c|c|c|c|c|c|c|}
\hline Glass & $\begin{array}{c}\text { heoretical } \\
\mathrm{Fe}^{+2} / \mathrm{F}+3 \\
\text { Ratio }\end{array}$ & $\begin{array}{c}\text { Glass, } \\
\text { mo } 100 \mathrm{~mL}\end{array}$ & $\begin{array}{l}\text { If Analyzed } \\
\text { Fe } e^{+2} \text { pprn }\end{array}$ & $\begin{array}{l}\text { Total Fe } \\
\text { by Ice. } \\
\text { pen }\end{array}$ & $\begin{array}{l}\text { Calculated } \\
\text { Fe+3 by icp } \\
\text { and IC }\end{array}$ & $\begin{array}{l}\mathrm{Fe}^{+2} / \mathrm{Fe}^{+3} \\
\mathrm{Ratho} \\
\end{array}$ \\
\hline Wv202 & $0 * 20$ & 26 & 3.0 & 21.7 & 18.7 & 0,16 \\
\hline WV202 & 0.20 & 36 & 5.1 & 29.3 & 24.2 & 0.21 \\
\hline WV202 & 0.20 & 30 & 4.2 & 23.3 & 19.1 & 0.22 \\
\hline PSCM-21 & 0.03 & 20 & 0.53 & 15.2 & 14.7 & 0.036 \\
\hline
\end{tabular}




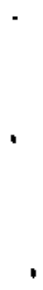

. 


\section{REFERENCES}

Batiford, C. F. 1977. Color Generation and Control in Glass. Elsevier Scientific Publishing Co., New York, pp. 16-33.

ancraft, 6. M. 1973. Mossbauer Spectruscopy. An Introduction for Inorganic Chemists and Geochemists. John Wiley and Sons, New York.

gancroft, G. M., et al. 1966. "Mossbauer Spectra of Iron (III) Dlketone Complexes." J. Chem, Soc* (A) $1966-1971$.

foon, I. A., and W. S. Fyfe. 1971. "Mossbater Investigation in the System $\mathrm{Na}_{2} \mathrm{O}-\mathrm{FeO}-510$." chem. Geol. $7: 153-169$.

Eoon, 3. H., and W. S. Fyfe. 1972. "The Coordination Number of Ferrous Ions in silicate Glasses." Chem, Geol. 10(4):287-298*

Close, W. P., and 3. F. Tillman. 1969. "Chemical Analys is of Some Elements in Oxidation-Reduction Equilioria in Silicate Glasses." Glass Technol. $10(5): 134-146$.

Dowty, E., and D. H. Lindsley. 1973. "Mossbater Spectra of Synthetic Hedenberyte-Ferrosilite Pyroxene." Amer. Mineralogist 58:850-868.

Goldman, D. S. 1983. "0xidation Equitibrium of Iron in Borosilicate Glass" 4. Aner. Cer. Soc. 66(3):205-209.

Goldman, D. S., and D. W. Brite. 1984. "Redox Characterization of Simulated Nutelear Waste blass." PNL-5A-11892, presented at the Anerican Ceramic Society annual meeting, April 21-May 3, 1984, Pittsburgh, Pennsylvania (accepted for publication in the J. Amer. Cer. Soc.)

Bolman, 0. S., D. W. Brite, and W. C. Richey. 1985. "lnvestigation of Foamm ing in Liquidumed Melting of Simulated Nuclear Waste Glas5." PNL-5A-12211, presented at the Anerican Ceranic Society annual meeting, Aprit 21-May 3 , 1984, Ptttsburgh, Pennsylvanta (accepted for publication in the y. Aner. cer. $30 \mathrm{c}$.$) .$

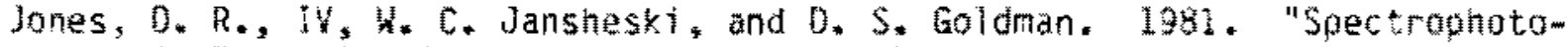
netric betermination of Recuced and Total Iron in olass with 1,10 Phenagthrolene." Anal. Chem. 53:923m924.

Melluger, G. B.; and J. L. Daniel. 1983. Approved Reference and Testing Materials for Use in Nuclear Waste Management kesearch and Development Programs. PNL-4955m, Pacific Northest Laboratory, Richland, Washington.

Hysen, B. 0., F. Seifert, and 0. Virgo. 1980 . "structure and Redox Equil ibria of Iron-Bearing Silicate Liquids. Amer. Nineralogist 65:867-884. 
lusen, B. 0., and D. Virgo. 1978. "influence of Pressure, Temperature, and

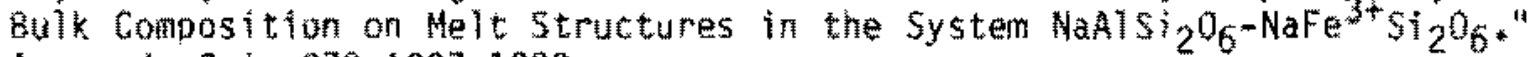
Aner* t. Sci. 270:1307-1322,

Mysen, B. 0., N. Virgo, and F. A. Seifert. 1984. "Redox Equilibria of Iron in Altaline Earth Silicate Melts: Relationshios Between Melt Structure, Oxygen Fugacity, Temperature and Properties of Iron-bearing sillcate Liquids." Amer. Mineralogist 69:834-847.

Schreiber, $H$. 0. et al. 1984, "An Electromotive Force Series in Borosilicate alass-Forming Melt." Com. Amer. Cer. Soc. C-106-108.

Senreiber, H. D., et a1. 1983. "Prectoltation of Iron, Cobalt and Nickel Metal from Borosilicate Melt." Glastech. Ber. 56ki2):1017-1022.

Taragin, M. F., and J. C. Elsenstein. 1970. "Mossbauer Effect in some Complex Borosilicate alasses." J. Non-Cryst. Solids 3:311-316. 


\section{DISTR IBUTION}

No. of

Coples

DFFITE

30 DoE Technical Information Center

R. D. Walton, Jr* OP-123

DoE office of Defense Waste

Byproducts Management

GTN

Washington, DC 20545

J. A. Coleman, NE-25

DOE Office of Teminal waste

Disposal Remedial Action

GT

Washington, DC 20545

T. H. Molntosin

Dof office of Termina! Waste

Jisposal \& Remedial Action GT:

Washington, DC 20545

4. B. Zorn, NE- 25

DOE Office of Terminal Waste

Disposal Remedial Action

GTV

Wastington, DC 20545

W. H. Hannum

DOE West Valley operations office

P.0. Box 191

West Valley, Ny 1417

J. 0. Hamric

DoE Idaho operations Office

550 Second Street

Itaho Falls, I0 83401

J. 8. Whitsett

DOE Idaho operations office

550 second Street

Idaho Falls, 10 g3401
No. of

Copies

L* Lanni

DoE San Francisco Operations

1333 Broadway

San Francisco, CA 94612

G. R. Derter

DOE Savannah River Operations Officte

P.0. B०० A

Aiken, SC 29801

C. S. Abrams $/ J .11$. Kittel

Acgonne Fational Laboratory

9700 South Cass Avenue

Argonne. IL b0439

M. J. Stelndler/2. E. Trevorrow

Argonne National Iaboratory

9700 South cass Avenue

Argonne, IL 60439

0. Rawles

管attelle Nemorial insticute

Project Management Ditision

505 king Avenue

Columbus, OH 43201

F. Holzer

Lamence Livernore bationa? Laboratory

University of Catifornia

P.0. Box 800

Livernore, CA 94550

D. T. Oakley. $M 5671$

Los Alanos Scientific Laboratory

$P, 0$, Box 1663

Los Alamos, NM 87\%44

T. H. Row

Dak Rigge National Laboratory

P.0. Pox $X$

Dak Ridge, TH 37330 
ป. 0. Blomeke

Dak Ridge Rationa: Laboratory

P. O. Box Y

Dak Ridge, TN 37830

Technical Library

Sandia Laboratories

P.0. Box 5800

Mlouquerque, M 87185

B. R. Wheeler

Westanghouse Idano Nuclear Co., Inc.

P. O. Box 4000

Idaho Falls, ID 83401

M. D. boersma

६. I. du Pont de Nemours Company

Savannah River Laboratory

Aiken, SC 29801

J. L. Crandall

E. I. du Pont de Nemours Company

Sayannah River Laboratory

Atken, SC 29801

E. 1. Hennelly

E. L. du pont de Venours Company

Savannah River Lacoratory

Aiken, SC 29801

L. L. Kilpatrick/L. M. Lee

E. I. du Pont de Nemours Company

Savannah River Laboratory

Alken, SC 29801

S. Mipthak

E. 1. de Pont de Nemours company

Savannah River Laboratory

Aiken, SC 29801
M. J. Plodinec

E. 1. du Pont de Nemours Company

Savannah River Laboratory

Alken, SC 29801

R. M. Wlace

E* 1. du pont de Nenours company

Savannah River Laboratory

Aiken, SC 29801

E. A. Jennrich

ECABG Idaho

P.0. Box 1525

Idaho Falls, ID 83415

K. V* Gubert/P. G. Hagen

Rockwell international

pocky flats Plant

P. $0.80 \times 464$

Golden, 0080401

C. C. Chapman

West Valley Nuciear Services

Company

P.0. $30 \times 191$

West valley, Ny 14172

3. C. Coynar

West valley huciear Services

Company

P. 0. Box 191

West Valley, NY 14171

L. R. Eisenstatt

West Valley Nuclear Services

company

P. D. Box 191

West valley, Ny 14171

1. L. Knabenschum

West valley Nuclear Services Company

P.O. Box 191

West Valley, NY 14171 
No. of

Cooies

3. E. Krauss

West Valley Nutlear Services

Company

P. O. Box 191

west Valley, NY 14171

J. M. pope

West Valley Nuclear Services

Company

P.0. 80x 191

West Valley; W 14171

W. A, Freeby/J. L. Jardine

Becheel Hational, Inc.

P.0. Box 3965

San Francisco, CA 94119

1.. I. Hench

Department of Materiass Science

Engheering

University of Fiorida

Gainesville, Fi. 32611

1. L. Larocea Chairman

Energy Research Development Authority

Empire State Plaza

Aloany, Ny 12223

ONSITE

6 DOE Richland Dperations office

E. A* Bracken

G. J. aracken

i. J. Broderick

M. J. Platuta

M. W. Shupe

U. D. White

9 Rockwell Hanford Operations

R. N. Gurley

1. M. Henderson

Q. D. Prosser

J. H. Roecker

K. R. Sthan
No. of

cootes

H. J. Smith

R. 3. Thompson

D. D. Hodrich

File copy

2 Westinghouse Hanfort Company

R. E. Lerch

U. D. Watrous

4) Pacific northwest Laboratory

H. 3. Bjorklund

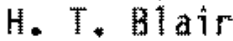

W. F. Bonner

D. J. Bradley

R. A. Brouns

L. L. Burger/L. A. Bray

R. D. Scheele

H. C. Burkholder

J. R. Carrell

1. A. Chick

T. 0. Chikalla

E. L. Courtright

S. K. Eller

L. J. Ethridge

D. S. Goldrian (10)

R. W. Goles

M. S. Hanson

F. E. Hart

L. K. Holton

1. H. iarrett

0. E. Knowiton

d. L. Kunn

1. M. Latkovich

J. L. McElroy

G. L. Mclay

d. E* Mendel/M. D. Merz/

6. B. Mellinger

J. E. Minor

L. G* Morgan

d. M. Perez

J.A.A. Roberts

W. A. Ros

P. A. Scot

Publisheng Coordination (2)

Techntcal Information (5) 
